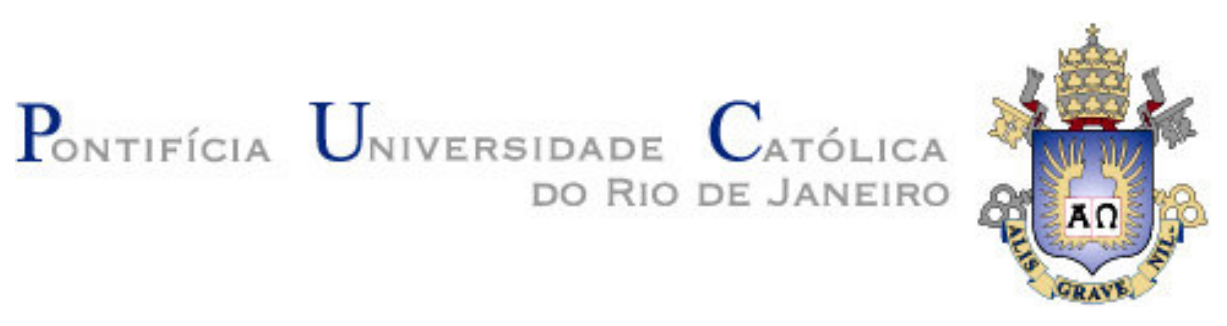

Daniel Sousa do Amaral

\title{
A Influência da Confiança Organizacional nos Índices de Rotatividade e Absenteísmo do Setor de Transporte: Uma Análise Comparativa de Casos
}

Dissertação de Mestrado

Dissertação apresentada ao Programa de Pósgraduação em Administração de Empresas da PUCRio como requisito parcial para obtenção do título de Mestre em Administração de Empresas

Orientadora: Prof ${ }^{a}$. Patrícia Amélia Tomei 


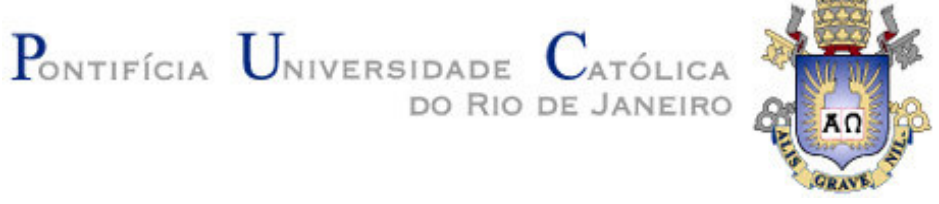

Daniel Sousa do Amaral

\begin{abstract}
A Influência da Confiança Organizacional nos Índices de Rotatividade e Absenteísmo do Setor de Transporte: Uma Análise Comparativa de Casos
\end{abstract}

Dissertação apresentada como requisito parcial para obtenção do grau de Mestre pelo Programa de PósGraduação em Administração de Empresas do Departamento de Administração da PUC-Rio. Aprovada pela Comissão Examinadora abaixo assinada.

\author{
Profª. Patricia Amelia Tomei \\ Orientadora \\ Departamento de Administração - PUC-Rio
}

Profa. Flávia de Souza Costa Neves Cavazotte Departamento de Administração - PUC-Rio

Prof. Giuseppe Maria Russo

Dedix Assessoria Técnico-Científica Ltda.

Profá. Mônica Herz

Vice-Decana de Pós-Graduação do CCS - PUC-Rio

Rio de Janeiro, 29 de março de 2016 
Todos os direitos reservados. É proibida a reprodução total ou parcial do trabalho sem autorização da universidade, do autor e da orientadora.

\section{Daniel Sousa do Amaral}

Graduou-se em Economia no IBMEC em 2010. Cursou Pós-Graduação Lato Sensu em Direito Societário e Mercado de Capitais na Fundação Getúlio Vargas em 2011.

Ficha Catalográfica

Amaral, Daniel Sousa do

A influência da confiança organizacional nos índices de rotatividade e absenteísmo do setor de transporte: uma análise comparativa de casos / Daniel Sousa do Amaral; orientadora: Patricia Amelia Tomei. $-2016$.

91 f. ; $30 \mathrm{~cm}$

$\begin{array}{ccc}\text { Dissertação (mestrado) } & & \\ \text { Universidade Católica do Rio de } & \text { Pontifícia } \\ \text { Janeiro, }\end{array}$ Departamento de Administração, 2016.

Inclui bibliografia

1. Administração - Teses. 2. Confiança organizacional. 3. Absenteísmo. 4. Rotatividade. I. Tomei, Patricia Amelia. II. Pontifícia Universidade Católica do Rio de Janeiro. Departamento de Administração. III. Título.

CDD: 658 
Dedico esse trabalho especialmente aos meus pais, Eleusa e Valmir, por me apoiarem irrestritamente e fazerem tudo que está ao seu alcance para me proporcionar a melhor educação possível. 


\section{Agradecimentos}

Aos meus pais, Eleusa e Valmir, meus maiores exemplos, e ao meu irmão, Luan, por sempre estarem do meu lado.

A Professora Dra. Patrícia Amélia Tomei, pela orientação inspiradora, seus ensinamento e pelo apoio e dedicação em todos os momentos.

A todos meus amigos e familiares, por todo carinho e incentivo.

Aos professores do IAG, pelos ensinamentos e orientações.

As diretorias das empresas pesquisas, pelo suporte e confiança, tornando possível o desenvolvimento desse trabalho.

Finalmente, minha mais especial gratidão, a minha namorada, Paula, pela parceria, amizade e paciência, e por todo cuidado e carinho, os quais tornaram mais amena esta caminhada 


\section{Resumo}

Amaral, Daniel Sousa do; Tomei, Patrícia Amélia. A Influência da Confiança Organizacional nos Índices de Rotatividade e Absenteísmo do Setor de Transporte: Uma Análise Comparativa de Casos. Rio de Janeiro, 2016. 91p. Dissertação de Mestrado - Departamento de Administração, Pontifícia Universidade Católica do Rio de Janeiro.

Os estudos relativos à confiança têm proliferado na literatura nacional e internacional. Contudo, são poucos os estudos que focam a relação entre a confiança, o absenteísmo e a rotatividade nas organizações. Com o intuito de diminuir essa lacuna, essa dissertação tem como propósito analisar o impacto da confiança organizacional na rotatividade e no absenteísmo com base em duas premissas: (1) a confiança organizacional impacta diretamente a rotatividade, (2) quanto maior a confiança organizacional menor o absenteísmo. Para esta analise foi aplicado o questionário Escala de Confiança do Empregado na Organização (ECEO) elaborado por Tamayo e Oliveira (2008) para funcionários de duas empresas do setor de transporte de passageiros, localizadas na região metropolitana do Rio de Janeiro. As respostas dos 385 funcionários da empresa A e 222 da empresa B não apresentaram o mesmo padrão identificado nos estudos de Tamayo e Oliveira (2008). Entre os resultados encontrados ressaltamos que (1) quanto maior for a confiança na promoção do crescimento do empregado e na solidez organizacional, menor serão os níveis de rotatividade; (2) normas relativas à demissão de empregados não influenciam diretamente os níveis de rotatividade das organizações; (3) não é possível pressupor a influência da confiança organizacional no absenteísmo das empresas.

\section{Palavras-chave}

Confiança Organizacional; Absenteísmo; Rotatividade 


\section{Abstract}

Amaral, Daniel Sousa do; Tomei, Patrícia Amélia (Advisor). Role of Organizational Trust in turnover and absenteeism levels: A comparative case study on transport sector. Rio de Janeiro, 2016. 91p. MSc. Dissertation Departamento de Administração, Pontifícia Universidade Católica do Rio de Janeiro.

The studies on trust have proliferated in the national and international literature. However, the relationship between organizational trust, absenteeism and turnover is rarely discussed in the literature. In order to fill this gap, this dissertation aims to analyze the impact of organizational trust on the turnover and absenteeism levels, based on two premises: (1) organizational trust impact on turnover rate; (2) the higher the organizational trust, the lower the absenteeism rate. Therefore based on a qualitative methodology was carried out a comparative case study between two bus companies, located on greater Rio de Janeiro, with the questionnaires Trust Scale Employee of the Organization (ECEO) prepared by Tamayo and Oliveira (2008) for a sample of 385 employees in the company A and 222 in company B. The responses were submitted to descriptive analysis and the pattern of responses was not exactly the same as for the model developed by Tamayo and Oliveira (2008). This study concluded that: (1) the greater the confidence in promoting employee growth and the organizational soundness, the lower will be the turnover levels; (2) the results demonstrate a negative association between rules relating to the dismissal of employees and turnover levels; (3) it is not possible to assume the influence of organizational trust in absenteeism companies.

\section{Keywords}

Organization Trust; Absenteeism; Turnover 


\section{Sumário}

1 Introdução 12

1.1. Contexto 12

1.2. Objetivos 15

1.2.1. Objetivos Intermediários $\quad 15$

1.3. Delimitação do estudo 16

1.4. Relevância do estudo 16

1.5. Estrutura da Dissertação 17

2 Referencial teórico 19

2.1. Confiança 19

2.1.1. Desenvolvimento da Confiança 21

2.1.2. As Dimensões da Confiança 22

2.1.3. Confiança Organizacional 24

2.1.4. Confiança Interorganizacional $\quad 25$

2.1.5. Confiança Intraorganizacional $\quad 27$

$\begin{array}{ll}\text { 2.2. Rotatividade } & 29\end{array}$

2.2.1. Causas da Rotatividade 31

2.2.2. Consequências da Rotatividade 34

2.2.3. Intenção de Rotatividade 37

2.2.4. Taxa de Rotatividade 39

2.2.5. Mercado de Trabalho e Rotatividade no Brasil 41

2.3. Absenteísmo 44

2.3.1. Características Relevantes para o Absenteísmo 45

2.3.2. Taxa de Absenteísmo 47

3 Metodologia $\quad 49$

3.1. Tipos de pesquisa (Design da Pesquisa) 49

3.1.1. Classificação quanto à sua finalidade 49

3.1.2. Classificação quanto aos objetivos mais gerais 50

3.1.3. Classificação quanto aos métodos empregados 50

3.2. Questionário de Pesquisa 51

3.2.1. Escala de Confiança do Empregado na Organização (ECEO) 51

3.3. Universo e Amostra $\quad 55$

3.4. Procedimentos e Instrumentos de Coleta de Dados 55

3.5. Análise e Interpretação dos Dados 56

3.6. Limitações do Método 56

4 Contextualização das Empresas $\quad 58$

4.1. O Transporte Público no Brasil 58

4.2. O Motorista de ônibus 61

4.3. As Empresas Estudadas 62

4.3.1. Empresa A 63

4.3.1.1. Liderança 63

4.3.1.2. Gestão da Qualidade 64

4.3.2. Empresa B 65

4.3.2.1. Mudanças na Gestão 65 
4.4. Perfil da Rotatividade das Empresas Analisadas 66

4.5. O Absenteísmo das Empresas Analisadas 68

5 Análise dos Resultados $\quad 71$

5.1. Análise e Discussão 71

5.1.1. Promoção do Crescimento do Empregado 73

5.1.2. Solidez Organizacional 74

5.1.3. Reconhecimento Financeiro Organizacional 75

5.1.4. Padrões Éticos 76

5.1.5. Normas Relativas à Demissão de Empregados 77

5.1.6. A Influência da Rotatividade nas Cinco Dimensões 77

6 Conclusão e Recomendações 80

$\begin{array}{ll}7 \text { Referências bibliográficas } & 81\end{array}$

8 Anexo $1 \quad 90$ 


\section{Lista de tabelas}

Tabela 1: Dimensões da Confiança .....................................................53

Tabela 2: Dados Mensais Município do Rio de Janeiro - 2014 ................59 59

Tabela 3: Taxas de Rotatividade das Empresas ....................................67

Tabela 4: Taxas de Absenteísmo das Empresas ..................................68 68

Tabela 5: Confiança na Organização - Frequência (Empresa A) ............71

Tabela 6: Confiança na Organização - Frequência (Empresa B) .............72

Tabela 7: Confiança na Organização - Escore Médio .............................73 


\section{1 \\ Introdução}

\section{1.}

Contexto

A complexidade do mundo contemporâneo, com mudanças imprevisíveis acontecendo com uma rapidez jamais vista em qualquer outro momento histórico, faz com que as empresas encontrem dificuldades em previamente estabelecer planos para responder a crises, contingências ou outros eventos que possam impactar significativamente os negócios (HAMEL \& VÄLIKANGAS, 2003; SOMERS, 2009). Assim, o mercado cada vez mais competitivo exige das organizações um aprimoramento constante e uma busca contínua por novas formas de alcançar melhores resultados (PEREIRA, 2008).

Zanini et al. (2007) caracterizam o cenário atual como a "Nova Economia", na qual as organizações têm se mostrado imersas em um contexto de incerteza constante. Fatores como clientes, competidores, tecnologia e sociedade favorecem o acirramento da busca pela garantia da competitividade, tornando o ambiente organizacional envolto em frequentes mudanças e adaptações.

Sendo assim, os autores Zanini et al. (2007) apresentam a promoção da confiança como forma de amenizar essa sensação de incerteza que afeta as relações de trabalho e como "mecanismo eficiente de controle para conferir flexibilidade organizacional, descentralização e para a coordenação de tarefas específicas relacionadas à natureza da informação e aos sistemas de produção".

Complementando esse posicionamento, Luhmann (1996) considera a confiança como um mecanismo básico que reduz a incerteza e garante mais segurança para as escolhas que se fazem necessárias, na medida em que permite a criação de pressupostos quanto a comportamentos futuros do outro e possibilita o estabelecimento da interação social e sua manutenção ao longo do tempo. Ela contribui para a redução da sensação de vulnerabilidade das pessoas favorecendo sua capacidade de ação e estimula a contribuição para um processo de trabalho cooperativo (FISHER \& NOVELLI, 2008).

Do ponto de vista organizacional, a confiança mostra-se como uma condição indispensável ao bem-estar dos colaboradores na organização, 
gerando comportamentos congruentes com os seus objetivos e proporcionando vantagem competitiva considerável (CAETANO \& SOUSA LIMA, 2007).

Considerada como uma variável de crescente interesse para a investigação em psicologia social, comportamento organizacional e outras áreas correlatas, a confiança organizacional tem sido mencionada como fator essencial para a compreensão das sociedades (LUNDÄSEN, 2008), importante influência no desempenho, na eficácia e na eficiência das organizações (MARIOTTI, 2004), além de gerar satisfação, motivação, eficiência e desempenho superior dos empregados (ZANINI et al., 2007), e exercer relevante papel no comportamento cooperativo e no controle da organização (KRAMER, 1999).

Como foi observado por Kramer (1999), "esse interesse tem sido alimentado, pelo menos em parte, pelas evidências de que a confiança tem uma série de benefícios importantes para as organizações e seus membros” (p.569).

Em face ao aumento de estudos sobre o fenômeno da confiança e de suas possíveis aplicações, considera-se relevante analisar o impacto da confiança na rotatividade e absenteísmo das organizações, uma vez que dados históricos comprovam altas taxas de rotatividade no caso brasileiro.

De acordo com os relatórios divulgados pelo Departamento Intersindical de Estatísticas e Estudos Socioeconômicos (DIEESE) os níveis de rotatividade no Brasil apresentaram crescimento nos últimos anos, apontando uma taxa de $45,1 \%$ em 2001; 43,6\% em 2004; 46,8\% em 2007; 52,5\% em 2008; 49,4\% em 2009; 53,8\% em 2010 e 64\% em 2012. O relatório também apresenta uma divisão das taxas de rotatividade em sete setores e subsetores de atividades econômicas, onde os setores de construção civil, agricultura e comércio ocupam os três primeiros lugares, respectivamente. Já o setor de serviços, do qual fazem parte as empresas a serem estudadas nesse trabalho, apresentou uma taxa de rotatividade de 59\% em 2012, ficando em quarto lugar no ranking nacional. Finalmente, os setores de indústria de transformação, indústria extrativa mineral e serviços de utilidade pública ocuparam o quinto, sexto e sétimo lugar respectivamente (DIEESE, 2014).

A curta duração dos contratos de trabalho é uma característica do mercado de trabalho brasileiro, além de ser um indicador de aumento da flexibilidade no padrão de contratação, já que, anualmente, o número de desligamentos é crescente, de acordo com dados da Relação Anual de Informações Sociais (RAIS). Em 2000 esse número era em torno de 4,4 anos, reduzindo a 3,9 anos em 2009. Já no ano de 2012, observou-se que os contratos que duram menos de seis meses correspondiam a cerca de $45 \%$ do total de desligamentos e em 
cerca de $65 \%$ dos casos sequer atingiram um ano completo. Diante de uma comparação internacional com 25 países, o Brasil apresenta tempo médio de trabalho mais baixo. Somente quando é feita uma comparação com os Estados Unidos é que o Brasil apresenta o tempo médio de emprego superior em cerca de sete meses (DIEESE, 2011; DIEESE 2014).

Outro bom indicador para medir as práticas de gestão de pessoas e o comportamento social dos empregados é o absenteísmo, ou genericamente, falta ao trabalho, uma das principais estratégias de resistência ou de enfrentamento dos trabalhadores face às organizações, o que afeta direta ou indiretamente o resultado organizacional (BERNSTORFF \& DAL ROSSO, 2008).

As empresas brasileiras atuam no contexto de altas taxas de rotatividade como se esta fosse uma característica "natural" do mercado de trabalho (MOBLEY, 1992). E essa conclusão é reforçada pelos dados da RAIS, uma vez que o estoque de trabalhadores formalmente contratados no país apresenta resultado positivo desde 1998, com taxas de crescimento dos empregos formais depois de 2003, mesmo nos anos em que a economia brasileira não cresceu ou pouco cresceu (DIEESE, 2014).

Na mesma linha de pensamento, Gonzaga (1998), ao estudar a relação entre qualidade de emprego e rotatividade, defende que o grande problema do mercado de trabalho brasileiro é a baixa qualidade dos postos de emprego, e não a escassa criação dos postos de trabalho.

Além disso, o autor destaca que é importante considerar que o baixo nível de educação, leva a uma baixa capacidade de aprendizado e, consequentemente, os retornos de investimento em treinamento de atividades específicas serão mais baixos. Logo, menor é o tempo esperado de duração da relação de trabalho, o que se faz representar nas altas taxas de rotatividade (GONZAGA, 1998).

O setor de transportes, apesar de não ser considerado um dos campeões em rotatividade e absenteísmo, se enquadra na situação acima descrita, uma vez que apresenta déficit na oferta de mão de obra especializada, principalmente de motoristas de ônibus para transporte de passageiros, o que reduz ainda mais a duração dos contratos de trabalho.

Diante disso, buscou-se avaliar a influência da confiança organizacional a partir de duas premissas, quais sejam: 1) Quanto maior a confiança organizacional, menor será o índice de rotatividade das empresas de ônibus, e 2) Quanto maior a confiança organizacional, menor será o índice de absenteísmo das empresas de transporte de passageiros. 
Com base nas premissas descritas, este trabalho analisa a seguinte questão chave: A confiança organizacional impacta diretamente os níveis de rotatividade e absenteísmo das empresas de transporte de passageiros?

\section{2.}

Objetivos

O objetivo principal deste trabalho é analisar o impacto da confiança organizacional nos níveis de rotatividade e absenteísmo das empresas de transporte de passageiros.

\subsection{1.}

Objetivos Intermediários

Para o alcance do objetivo principal foram formulados alguns objetivos intermediários.

São eles:

a) Conceituar confiança do empregado na organização, rotatividade e absenteísmo;

b) Apresentar os conceitos e as dimensões de confiança organizacional, rotatividade, e de absenteísmo;

c) Apresentar instrumentos metodológicos que favoreçam a mensuração da confiança organizacional e detalhar a escolha metodológica de dois casos de empresas de transporte cariocas;

d) Apresentar os casos das empresas escolhidas;

e) Aplicar questionários da Escala de Confiança do Empregado na Organização (ECEO) elaborado por Oliveira e Tamayo (2008);

f) Analisar os resultados encontrados relacionando a confiança na organização com a rotatividade e absenteísmo;

g) Comparar os resultados encontrados nas duas organizações pesquisadas para compreender o impacto da confiança do empregado na organização na sua rotatividade e no absenteísmo. 


\section{3. \\ Delimitação do estudo}

Este estudo volta-se mais especificamente para abordar a questão da confiança sob o ponto de vista específico das relações de trabalho entre rodoviários e duas empresas de transporte de passageiros da Baixada Fluminense. Tal ângulo de análise se mostra interessante e importante em função da alta rotatividade de mão de obra apresentada pelo setor nos últimos anos e da baixa produtividade verificada no setor.

A relação do constructo confiança entre os diferentes agentes que compõem o ambiente do setor de transporte de passageiros no estado do Rio de Janeiro, como por exemplo, empresas de ônibus, governo do estado, secretaria de transportes, sindicatos patronais e de classe, influenciam significativamente as políticas de recursos humanos das empresas de transportes. Vale destacar que, embora a relação entre esses agentes e o nível de confiança interorganizacional estabelecido entre eles não seja o foco deste estudo, é uma limitação da pesquisa que deve ser considerada.

Este projeto propõe um estudo de caso comparativo, a ser analisada a relação e o impacto da confiança do empregado na organização com os índices de rotatividade e absenteísmo apresentado pelas empresas nos últimos anos. Ao aplicar a pesquisa em uma organização busca-se encontrar esta relação e validar a importância da confiança na retenção do empregado e na formação de uma relação afetiva com a organização.

\section{4.}

\section{Relevância do estudo}

A pesquisa será importante para definir como as empresas de transporte de passageiro devem enxergar e conduzir as relações de trabalho com seus funcionários. O grande déficit de motoristas de ônibus, em função do aquecimento do mercado de trabalho no mercado de caminhões, alinhado às dificuldades impostas para a emissão de carteira de motorista profissional, bem como a rotina estressante dos motoristas de ônibus e o transito caótico do Rio de Janeiro, faz com que as políticas de retenção dos rodoviários ganhem importância na agenda das empresas de ônibus.

Diante desse cenário alarmante e da relevância do tema para toda população fluminense, esse estudo pretende apontar de que forma a confiança dos rodoviários nas organizações afeta os índices de rotatividade e absenteísmo das empresas. 
As informações que esse estudo pretende produzir podem se mostrar de interesse para as empresas de ônibus, a classe rodoviária e usuários do transporte público.

Do ponto de vista das empresas de ônibus, os resultados gerados pela pesquisa poderão fundamentar políticas de retenção de funcionários, bem como treinamentos específicos e medidas gerenciais para solucionar questões que possam contribuir diretamente para a melhora dos índices e das políticas de Recursos Humanos.

Do mesmo modo, a pesquisa poderá contribuir para a melhoria das condições de trabalho dos motoristas de ônibus, bem como para a valorização do rodoviário no exercício da sua função.

Já o interesse dos usuários de ônibus nos resultados da pesquisa é evidente, em função da expectativa da melhora na qualidade do serviço prestado, uma vez que os resultados produzidos poderão gerar políticas de aumento da satisfação dos rodoviários, que passarão a trabalhar sob um estresse menor e, como consequência, prestarão um serviço de maior qualidade para todos os usuários dos ônibus.

É importante destacar também que os resultados a serem alcançados pelo presente estudo poderão ser úteis para toda a população do Estado do Rio de Janeiro, posto que, atualmente, a gigantesca frota de ônibus em circulação em ruas e avenidas das cidades divide espaço com milhares de outros tipos de veículos, como automóveis, motocicletas e caminhões, que juntos tornam o trânsito quase impraticável, levando toda população a graus elevados de estresse e tensão.

\section{5.}

\section{Estrutura da Dissertação}

O presente estudo é composto de seis capítulos.

O primeiro capítulo - Introdução - contém uma visão geral do problema de pesquisa e contextualiza a teoria utilizada como base, ressaltando os objetivos principal e intermediário da pesquisa, as hipóteses, a delimitação, a relevância e a estrutura do estudo.

O segundo capítulo - Referencial Teórico - abordará a revisão da literatura dos constructos confiança organizacional, rotatividade e absenteísmo. A revisão do referencial teórico será base para a preparação dos questionários de pesquisa, instrumento de coleta dos dados primários. Além de servir de base 
para a análise dos dados levantados em campo e também para a conclusão do estudo.

No Capítulo 3 - Metodologia - será descrita a abordagem metodológica utilizada para a realização do presente estudo, apresentando o detalhamento do tipo de pesquisa, a justificativa da seleção dos participantes, os instrumentos adotados para coleta de dados, a apresentação do roteiro da entrevista, a forma como será feita a análise e tratamento dos dados, bem como as limitações do método utilizado.

O capítulo 4 - Contextualização das Empresas - faz um breve balanço acerca do transporte público no Brasil e no estado do Rio de Janeiro, faz também uma breve descrição da função exercida por motorista de ônibus, além de apresentar um histórico das empresas que serviram de estudo de caso, detalhando suas principais características, estilo de gestão e o motivo da sua escolha, além de apresentar um balanço dos índices de rotatividade e absenteísmo das empresas nos últimos anos.

A análise e a interpretação dos dados obtidos nas respostas aos questionários estarão contidas no Capítulo 5 - Análise dos Resultados. Nesse capítulo constam as seguintes análises: caracterização dos participantes da pesquisa, validade e confiabilidade da escala empregada, análise das correlações entre as variáveis e verificação das premissas definidas. O capítulo termina com a discussão das relações encontradas entre os constructos avaliados.

O Capítulo 6 - Conclusões e Recomendações - apresentará a conclusão da pesquisa, incluindo as considerações finais e listando algumas sugestões para futuras pesquisas.

Ao final, serão apresentadas as referências bibliográficas, seguidas dos apêndices e anexos utilizados durante o estudo e selecionados para serem incluídos nesse documento por serem relevantes para a análise do resultado. 


\section{2 \\ Referencial teórico}

Neste capítulo será apresentado o referencial teórico, que está dividido em quatro seções para aprofundamento dos conceitos que são base para entendimento da pesquisa, análise dos dados levantados em campo e conclusão do estudo. A primeira seção apresenta os conceitos e as dimensões de confiança, confiança organizacional e confiança intraorganizacional. A segunda e a terceira seções apresentam as definições relevantes de rotatividade e absenteísmo, respectivamente. Finalmente, a quarta seção apresenta a importância do estudo relacionando os constructos.

\section{1.}

\section{Confiança}

Para tratar do referencial teórico sobre confiança parte-se de uma definição conceitual mais geral sobre o tema, posteriormente busca-se diferenciar confiança organizacional e intraorganizacional.

Diversas correntes da literatura têm conceituado confiança de diferentes maneiras. Uma das definições seminais do constructo confiança é oriunda da psicologia e foi elaborada por Rotter (1967, p.651) como sendo "a expectativa generalizada mantida por um indivíduo ou um grupo de que a palavra, promessa, verbal ou escrita, de outro indivíduo ou grupo pode ser confiada". Já os sociólogos veem a confiança em propriedades socialmente inseridas nas relações entre as pessoas (ROUSSEAU et al., 1998).

McEvily (2011) argumenta que a confiança tem evoluído a partir de dois paradigmas dominantes: a Economia, que enfatiza medidas comportamentais; e as Ciências Sociais, que enfatizam medidas atitudinais. Medidas comportamentais são enraizadas na teoria do jogo econômico e possibilitam abordagens baseadas no risco para o estudo de confiança, enquanto as medidas atitudinais consideram a confiança como um estado psicológico.

Para Whipple et al. (2013), confiança é um termo amplo que engloba um grau significativo de complexidade e potencialmente de desentendimento. A confiança pode ser conceituada com base no que implica (por exemplo, o que a 
pessoa que confia examina com relação à outra parte), onde a confiança se localiza (por exemplo, a nível individual, organizacional ou interorganizacional) e, até mesmo, como a confiança se desenvolve (por exemplo, aspectos longitudinais da confiança, incluindo a perda e recuperação potencial de confiança).

A dificuldade em não se ter uma única definição para o constructo entre as diversas disciplinas motivou Rousseau et al. (1998, p.651) a proporem uma definição consensual. Para eles, "confiança é um estado psicológico que compreende a intenção de aceitar uma vulnerabilidade baseada em expectativas positivas das intenções ou comportamentos de outro". De forma mais simples, Robbins (2002, p.276) afirma que "confiança é uma expectativa positiva de que outra pessoa não agirá de maneira oportunista, isto é, não irá nos prejudicar, mesmo que tenha oportunidade para fazê-lo".

Mesmo havendo divergências sobre a definição do constructo confiança entre as diversas disciplinas, identifica-se pelo menos um ponto em comum a todas as áreas: as condições que devem existir para que a confiança seja desenvolvida. A primeira é risco, ou seja, a probabilidade de perda, quando interpretada por uma das partes decisoras; a segunda é interdependência, onde os interesses de uma parte não podem ser atingidos sem a colaboração de outra (ROUSSEAU et al., 1998).

Em relação à primeira condição, Giddens (1991, p. 42) afirma que risco e confiança "se entrelaçam entre si". A confiança serve para minimizar os riscos, mas, um risco aceitável é fundamental para que a confiança se mantenha. Sato (2003, p.2) exemplifica isso quando descreve que, os "autores de um modo geral, convergem para a visão de que em um ambiente em que há confiança, o medo ou temor em agir, em realizar as atividades, em função da incerteza das consequências futuras, diminuem".

Já em relação segunda condição para que a confiança seja desenvolvida, a interdependência dos agentes, Bigley e Pearce (1998) destacam que se o indivíduo estiver em uma situação onde este não é vulnerável à ação de outros, a confiança não será necessária.

Robbins (2002), a respeito desta questão, afirma que as pessoas normalmente formam expectativas em relação ao comportamento dos outros a partir de sua história pessoal. Portanto, a confiança é um processo que depende de uma história baseada em algumas experiências relevantes. Em linhas gerais a confiança é influenciada pela existência de conhecimento e familiaridade entre as partes. $O$ autor acredita que é difícil a existência da confiança e de uma 
expectativa positiva sem que haja um prévio conhecimento entre aquele que confia e aquele que recebe a confiança. No mesmo sentido, Blau (1964) sugere que a existência ou não de confiança e o grau em que ela irá se desenvolver irá depender fundamentalmente da natureza do relacionamento entre as partes.

\subsection{1.}

\section{Desenvolvimento da Confiança}

Lewicki e Bunker (1994) sugerem que o desenvolvimento da confiança se dá em três estágios: se iniciando com uma forma mais racional de confiança, denominada "confiança baseada no cálculo"; se movendo para uma confiança menos calculista chamada "confiança baseada no conhecimento" e, finalmente, desenvolve a "confiança baseada na identificação" onde os valores se convergem e a confiança torna-se inerente ao relacionamento.

Por outro lado, Stark (2001) entende que o desenvolvimento da confiança parece ser um processo aprendido através do tempo, baseado nas informações armazenadas a respeito de determinada situação ou indivíduo. Além disso, o autor ressalta alguns fatores contextuais importantes para o desenvolvimento da confiança como familiaridade, o clima de justiça, comunicação, respeito e, principalmente, o relacionamento entre as partes. $O$ autor conclui que o maior fator contextual a ser considerado num contexto de trocas comerciais e sociais é o tipo de relacionamento entre os indivíduos.

Kramer e Tyler (1996) descrevem a confiança em três níveis: Micro (enfatizando as bases psicológicas da confiança e desconfiança), meso (explorando as concepções de trabalho) e o nível macro (envolvendo a influência das organizações sobre os padrões de confiança).

Worchel (1979) distingue a confiança nos três níveis, sendo o micro relacionado à crença, expectativa ou sentimento arraigado na personalidade. Ao nível meso, relacionado às transações interpessoais entre indivíduos e à expectativa em relação à outra parte. Por fim, o nível macro, relacionado à percepção do indivíduo junto à organização. Para Costa (2000) e Jeffries (2000), os níveis micro e macro estão associados ao que se chama de confiança interpessoal e organizacional.

Hosmer (1995) com base em várias perspectivas de pesquisa utilizados, comparando definições, ilustrando os principais pressupostos, e considerando as diferenças contextuais divide a confiança em cinco categorias: (1) as expectativas individuais ("comportamento não racional, com base em experiências passadas e projeções futuras"); (2) relações interpessoais 
("comportamento não racional, com base em características e traços de ambos os indivíduos"); (3) as trocas econômicas ("comportamento economicamente racional, limitado por contratos e controles"); (4) estruturas sociais ("comportamento socialmente racional, dirigido por requisitos formais e informais obrigações"); e (5) princípios éticos, como uma importante questão a ser considerada no estudo da confiança.

\subsection{2.}

\section{As Dimensões da Confiança}

Além da afirmação de que não há consenso quanto à definição de confiança, outro ponto comum encontrado nos estudos sobre o constructo é a constatação de que se trata de um fenômeno multidimensional (CUMMINGS \& BROWLLEY, 1996).

McAllister (1995) distingue duas dimensões para a confiança: a cognitiva e a afetiva. Os resultados do seu estudo indicaram que a confiança cognitiva é antecedente da confiança afetiva, ou seja, há a necessidade de conhecimento prévio, ainda que estes sejam parciais ou mínimos para que se estabeleça a confiança de base afetiva. Apesar disso, o autor argumenta que a confiança não é necessariamente racional, embora seja necessário um grau, ainda que mínimo, de conhecimento e de "boas razões" para a decisão de confiar.

As dimensões do modelo proposto por Mayer et al. (1995): benevolência, capacidade e integridade, constituem-se em uma importante referência teórica. $A$ benevolência está relacionada à percepção positiva da ação de um para o bemestar do outro. Já a capacidade compreende o conjunto de competências que caracterizam um determinado indivíduo; e a integridade é a percepção de quem confia que o indivíduo alvo da confiança adere a um conjunto de princípios aceitáveis.

No mesmo sentido, Tomei e Lanz (2015) definem as três principais dimensões da confiança: integridade e consistência; competência e capacidade; lealdade, benevolência e abertura.

1) Integridade e consistência: se refere à honestidade e a confiabilidade; está relacionada à previsibilidade, segurança e capacidade de julgamento que uma pessoa demonstra nas situações.

2) Competência e capacidade: engloba as habilidades e conhecimentos técnicos e interpessoais do indivíduo. 
3) Lealdade, benevolência e abertura: é a disposição de proteger e defender outra pessoa; considerar de verdade os interesses dos outros, mesmo que estes não estejam necessariamente alinhados com os seus. Qualquer relação de confiança envolve vulnerabilidade e disposição de assumir um risco.

Dirks e Ferrin (2001) baseiam-se nos conceitos de percepção, justiça, integridade e vulnerabilidade ao risco para definir as bases da confiança em quatro dimensões: a dimensão afetiva, que se baseia na percepção de que a relação é especial com o referente; a dimensão cognitiva, que considera o outro íntegro e que agirá de modo justo, baseado na verdade; a disposição para o risco, tornando-se vulnerável ao outro e, finalmente, a dimensão global, que envolve as dimensões afetiva e cognitiva.

Schindler e Thomas (1993) apresentam cinco dimensões básicas que fundamentam $\mathrm{o}$ conceito de confiança: integridade (honestidade e confiabilidade), competência (habilidades, conhecimentos técnicos e interpessoais), consistência (segurança, previsibilidade e capacidade de julgamento), lealdade (disposição de proteger e defender outra pessoa) e abertura (acreditar na total confiança do outro no indivíduo).

Tzafrir e Harel (2002), também estabelecem cinco atributos da confiança:

1) Confiabilidade - estrutura-se nos comportamentos e procedimentos sistemáticos e consistentes, que são fortalecidos quando as promessas e os compromissos são cumpridos. O comportamento previsível como positivo reforça o nível de confiança em uma relação;

2) Capacidade - é a autoridade, a habilidade e o conhecimento para fazer o que é necessário de maneira eficaz e adequada;

3) Transparência - é a clareza, a exatidão no compartilhamento de informações, bem como a disponibilidade para a comunicação. Tendem a fortalecer os laços de confiança;

4) Cuidado - confiar implica acreditar que o outro não adotará atitudes oportunistas, que uma parte não tirará vantagem individualmente da outra, que uma parte terá cuidado e será benevolente com relação a outra;

5) Identidade - valores compartilhados são o veículo fundamental por meio do qual os indivíduos experimentam a confiança. Uma combinação positiva de sentimentos, interesses, opiniões, objetivos e valores nas relações de trabalho cria a identidade necessária 
para atingir a confiança. Significa harmonia, congruência, adesão e aceitação. Em situações nas quais há identidade entre as partes as expectativas aumentam, bem como a disposição de assumir riscos.

Para efeito deste estudo, a confiança organizacional e a confiança intraorganizacional darão o suporte teórico com relação ao constructo confiança.

\subsection{3. \\ Confiança Organizacional}

A confiança também desempenha um papel importante nas organizações, sendo por muitos, apontada como fonte de vantagem competitiva. Conforme Tomei e Lanz (2015, p.1), "a confiança facilita o compartilhamento de informações, minimiza as dificuldades de expressar preocupações no trabalho e a insegurança para colocar seu ponto de vista, além de aumentar a disposição de manifestar as opiniões livremente".

Segundo Costa (2000), a confiança organizacional refere-se à relação estabelecida com o sistema formal, sendo baseados em leis, regulamentos e nas práticas que mantêm a organização como um todo. Também pode ser vista como responsável por influenciar o desempenho no trabalho, o comportamento de responsabilidade do trabalhador, o comportamento de soluções de problemas, reconhecimento/sustentação de autoridades, a negociação de ganhos mútuos e o comprometimento organizacional (TZAFRIR \& DOLAN, 2004).

Para Mayer et al. (1995) a confiança organizacional está ligada à ideia da confiança no sistema, que possui a lei e as regras como intermediadoras para amenizar os riscos prováveis. Para Gilbert e Tang (1998) a confiança organizacional é considerada como um sentimento de confiança e apoio ao empregador, acreditando-se que ele será honesto e cumprirá seus compromissos. A confiança institucional, também denominada "confiança sistêmica" é "produzida na ausência de simpatias ou experiências pessoais".

Cummings e Bromiley (1996), por sua vez, consideram que confiança organizacional é o grau de confiança entre unidades de uma organização. Definem o constructo como sendo "a crença individual ou crença comum entre um grupo de pessoas que outro indivíduo a)faz esforço de boa fé para se comportar de acordo com o compromisso firmado explícita ou implicitamente; b) é honesto em quaisquer negociações que precedam o compromisso; e c) não toma vantagem excessiva de outro quando tiver oportunidade" (p.303). 
Schockley-Zalabak et al. (2000) definem a confiança organizacional como as expectativas positivas que um indivíduo tem sobre a intenção e comportamentos dos vários membros da organização, baseados nos papéis organizacionais, relacionamentos, experiências e interdependências.

Para Zanini (2007, p.13) "presente a confiança, os problemas contratuais que podem surgir numa relação de trabalho se reduzem significativamente, pois ela produz formas mais espontâneas e informais de cooperação, mediante a socialização dos indivíduos dentro de uma cultura existente". O autor descreve a confiança como "um mecanismo implícito de coordenação e controle de diversas tarefas organizacionais, aumentando a eficiência da relação contratual".

Considera-se também que confiança deve ser considerado um fator fundamental na gestão do ambiente organizacional por se tratar de um mecanismo por meio do qual os atores sociais reduzem a complexidade interna do seu sistema de interação pela crença na credibilidade de uma pessoa ou de um sistema (GIDDENS, 1991).

Segundo Fukuyama (1996) quanto mais alto o grau de confiança nas organizações maior a cooperação espontânea, e menos se precisa de "aparatos legais" como sistemas de normas e regulamentos, negociados ou coercitivos, para garantir a cooperação. Para ele, as organizações com nível mais alto de confiança internamente se tornam mais eficientes do ponto de vista econômico, pois não precisam investir tão fortemente nesses sistemas.

Seguindo a mesma linha de raciocínio, Kimbrough (1997) defende que a confiança e a desconfiança podem ter alto impacto no sucesso ou fracasso da organização, relacionando 0 alto desempenho a um sentimento de pertencimento em uma equipe e foca que os esforços devem ser baseados em expectativas positivas. Ainda de acordo com o autor, a confiança organizacional nasce da partilha de valores e capacita às pessoas trabalharem em conjunto, o que pode gerar mais conhecimento e inovação.

\subsection{4.}

\section{Confiança Interorganizacional}

Conforme Kramer (1999) o interesse pelo estudo da confiança entre organizações tem aumento em parte, pela evidência acumulada que a confiança tem um número de benefícios importantes para as organizações e seus membros.

Segundo Sydow (1998), confiança interorganizacional se refere à confiança mútua entre organizações que trabalham juntas em redes. A confiança 
interorganizacional suporta a formação de estratégias coletivas, facilita a coordenação de atividades econômicas, promove a troca de informações e o aprendizado organizacional, facilita o gerenciamento de conflitos organizacionais, contribui para uma diminuição significativa dos custos de transação, abre oportunidades para a ação estratégica, aumenta estabilidade da rede e prove um suporte para as mudanças organizacionais.

Segundo Zaheer et al. (1998), para a existência deste tipo de confiança, é necessária a existência da confiança entre os indivíduos, pois esses são os responsáveis pela junção dos diversos subsistemas da organização.

De acordo com Fiala et al. (2012) a confiança interorganizacional tem um efeito positivo sobre o desempenho, ao diminuir os custos de transação, além disto, a confiança interorganizacional parece ter o efeito de diminuir o nível de conflito entre as empresas. Palmatier et al. (2007) identificam quatro perspectivas teóricas que buscam relacionar a confiança interorganizacional e a performance, a perspectiva do comprometimento-confiança, a da dependência, dos custos de transação e das normas relacionais.

Para Ganesan (1994) a confiança entre as partes, em uma relação comprador fornecedor, se estabelece quando as ações, ou seja, o comportamento da outra parte é percebido como benevolente. Aspectos como honestidade e abertura ao lidar com a outra parte são importantes para estabelecer esta percepção.

No mesmo sentido, Doney e Cannon (1997) afirmam que a reputação de um fornecedor é definida de acordo com o que as empresas e as pessoas na indústria pensam a respeito da sua honestidade e preocupação com seus clientes. A reputação favorável é facilmente transferível entre empresas e aumenta a credibilidade do fornecedor (GANESAN, 1994). Se uma empresa compradora assume que a reputação do fornecedor é merecida, a confiança será concedida com base no histórico do fornecedor nas relações com outras empresas. Em outras palavras, os compradores inferem a confiabilidade de um fornecedor através das palavras e ações de outras pessoas e organizações. Portanto, o processo de transferência pode ser a base para prever uma relação positiva entre a reputação do fornecedor e confiança da empresa compradora.

Para Das e Teng (2001), a dimensão competência da confiança tem o maior efeito entre as dimensões na redução do risco percebido na relação entre empresas. A competência é baseada nos diversos recursos e capacidades de uma empresa. Os recursos podem incluir o capital, recursos humanos, propriedades físicas, poder de mercado, tecnologia e outros. Esses recursos e 
capacidades fornecem a base para a competência ou experiência que é necessária em alianças. Além disso, as empresas que foram bem sucedidos em alianças anteriores tendem a construir uma reputação de competência. A competência sugere uma alta probabilidade de conseguir que as coisas sejam realizadas com sucesso, o que equivale a um baixo risco de desempenho. Desta forma, a competência dá um firme senso de confiança de que o parceiro é capaz de realizar determinadas tarefas na aliança e o risco desempenho será percebido como relativamente baixo.

Segundo Zaheer et al. (1998) o argumento para o alcance de uma eficiência superior por meio dos relacionamentos organizacionais que envolvem confiança é que a confiança reduz a inclinação para o uso de medidas contratuais para se proteger do potencial comportamento oportunista do parceiro. Então, quando o relacionamento se dá em condições de baixa confiança, há a possibilidade de negociações longas e difíceis entre os parceiros sobre contingência não previstas devido à possibilidade de oportunismo ex-ante e ex-post de ambos. Em contraste, sob condições de alta confiança as empresas são menos inclinadas ao uso de salvaguardas contratuais para especificar, monitorar e reforçar acordos.

\subsection{5.}

\section{Confiança Intraorganizacional}

Considerando a importância da confiança no âmbito organizacional, conhecer a forma como se estrutura a relação de confiança entre o empregado e sua organização de trabalho é essencial. A relação entre pessoa-organização constitui a perspectiva intraorganizacional da confiança, de acordo com Tzafrir e Dolan (2004). Nesse sentido, Oliveira e Tamayo (2008, p.100) definiram a confiança do empregado na organização como sendo "o conjunto de cognições interdependentes que integra crenças a respeito de padrões éticos, credibilidade da comunicação, poder econômico da organização e capacidade desta de reconhecer o desempenho do empregado, tanto financeira quanto profissionalmente."

Para eles, este "esquema mental representa um conjunto de crenças do empregado sobre a manutenção de padrões éticos, a solidez econômica da organização e a capacidade desta em reconhecer os esforços dos empregados, honrar compromissos, obedecer a leis e normas. Sendo assim a confiança depositada na organização apoia-se nessas crenças elaboradas pelo empregado 
ao se relacionar e processar as informações do contexto organizacional." Oliveira et Tamayo (2008, p.101)

$\mathrm{Na}$ perspectiva de Schockley-Zalabak et al. (2000), confiança intraorganizacional é definida como as expectativas positivas que um indivíduo tem sobre a intenção e os comportamentos dos membros da organização, com base nos papéis organizacionais, relacionamentos, experiências e interdependências. A partir da abordagem cognitivista, Oliveira (2004) define a confiança do empregado na organização como as crenças a respeito de padrões éticos, credibilidade da comunicação, poder econômico da organização e sua capacidade de reconhecer o desempenho do empregado, tanto financeira quanto profissionalmente.

A outra vertente teórica sobre confiança intraorganizacional é representada pelo trabalho de Fukuyama (1996), e visualiza as diferenças quanto ao grau de confiança existente entre os membros da organização. Sob esse ponto de vista, quando há um alto grau de confiança do trabalhador na organização, a cooperação ocorre de forma espontânea, uma vez que as pessoas trabalham de acordo com normas éticas comuns. Em organizações de baixo nível de confiança, a cooperação não é espontânea.

De acordo com Ramacciotti (2007), sistemas de regras e regulamentos, previamente negociados e implantados, por vezes de forma coercitiva, substituem a confiança para assegurar a cooperação. Este aparato legal, que visa ao controle e à coerção para forjar a cooperação, agrega um ônus às atividades econômicas, ônus este que as sociedades e organizações de alto nível de confiança não têm de pagar, o que as torna mais eficiente do ponto de vista econômico.

De acordo com Robbins (2002) a confiança no contexto intraorganizacional é baseada em três diferentes aspectos: conhecimento, intimidação e identificação. A confiança baseada na intimidação é a mais frágil, pois, se sustenta no medo de que a qualquer violação ou inconsistência haverá algum tipo de represália da pessoa em quem se confia. A respeito da confiança baseada no conhecimento, o autor afirma que a maioria das relações organizacionais se enraíza nesta base. A previsibilidade do comportamento se apoia então, no histórico de interações e nas informações sobre a pessoa em quem se confia, dessa maneira é possível fazer previsões precisas acerca de seu comportamento, mesmo que esse não seja o esperado. Já a confiança baseada na identificação se estabelece quando as partes se entendem quanto à intenção, vontades e desejos do outro. Nesse nível de interação, os controles 
são mínimos, pois não há necessidade de monitoramento das ações do outro, visto que a lealdade é inquestionável.

Ainda sob o aspecto da confiança há que se analisar o contexto da relação laboral, e as expectativas refletidas nas percepções implícitas e explícitas envolvidas nessa relação, isso porque as expectativas claras podem ser pactuadas mediante contrato formal que preveem direitos e deveres das partes, porém, ainda existe aquele tipo de contrato não escrito que, segundo Rosseau (1995) preenche os espaços em branco deixados pelo contrato formal, pois, contratos envolvem promessas, sobre o futuro, que estão cada vez mais difíceis de serem cumpridas.

\section{2.}

\section{Rotatividade}

Ferreira e Siqueira (2005) consideram que o ambiente organizacional vive constantemente sofrendo interferências de vários agentes, tais como a escassez de recursos, concorrência, tecnologia, entre outros. Maximiano (1997) considera que, no passado, os administradores podiam tomar decisões sem levar em conta aspectos que hoje são extremamente relevantes, pois os ambientes eram menos sujeitos a mudanças e apenas a concorrência era ameaça importante. Os recursos pareciam ser infinitos e os problemas e variáveis a serem consideradas ocorriam em menor número.

Nas últimas décadas, no entanto, verificaram-se algumas mudanças no mercado de trabalho causadas pelo crescimento da economia e pelo aumento de competitividade entre as empresas. Junto a esses fatores a oferta de trabalho é aumentada e a procura por mão de obra se torna evidente. As empresas procuram profissionais qualificados, entretanto, a maioria dos países tem sofrido ou com escassez ou com falta de qualificação da mão de obra (PRICEWATERHOUSECOOPERS, 2011).

Uma vez que a procura por pessoal qualificado aumenta, os melhores profissionais tendem a procurar as melhores empresas para trabalhar, ou seja, aquelas que proporcionem ao empregado satisfação pessoal e profissional (ETZIONI, 1981). O aumento da demanda de funcionários nas organizações e a dificuldade de retenção destes gera como consequência o aumento da rotatividade de funcionários (GONZAGA, 1998).

A questão da rotatividade tem sido abordada recorrentemente no campo do comportamento organizacional, uma vez que o estudo da conduta humana no

ambiente de trabalho pode proporcionar às empresas aumento da 
competitividade através da análise dos fatores que exercem impacto direto sobre a produtividade (FERREIRA, 2001). Tendo em vista o cenário de competição globalizada no qual as organizações estão inseridas, o fenômeno da rotatividade pode revelar-se fonte de preocupação, já que a sua ocorrência pode ser reflexo de distorções nas políticas de recursos humanos (FERREIRA \& FREIRE, 2001).

O termo rotatividade, derivado da palavra inglesa turnover, refere-se à entrada e saída de empregados de uma empresa, podendo ser por livre e espontânea vontade do trabalhador ou por decisão da organização (MILKOVICH \& BOUDREAU, 2000). Para Mobley (1992, p.30), tal fenômeno é definido como a "suspensão da condição de membro participante de uma organização por parte de um indivíduo que recebia compensação monetária desta".

Ainda de acordo com Mobley (1992), a rotatividade se classifica como involuntária ou voluntária. A primeira trata-se do desligamento do funcionário por iniciativa da organização, podendo ocorrer nos casos de substituições com o intuito de melhorar o potencial humano existente; atendimento das demandas econômicas e financeiras do ambiente externo; e também em casos de aposentadoria e falecimento. Já a rotatividade voluntária ocorre quando o funcionário decide por iniciativa própria deixar a organização.

Corroborando a definição proposta por Mobley (1992) e Robbins (2002) conceitua rotatividade como a permanente saída e entrada de pessoal na organização, de forma voluntária ou involuntária. Para este autor, toda organização tem alguma rotatividade, que pode ser positiva, à medida que funcionários não essenciais ou que apresentam baixa produtividade deixam a organização.

No entanto, a rotatividade voluntária é a que parece ser mais prejudicial às organizações, pois pode se tratar do desligamento de empregados que apresentam bom desempenho na execução de suas tarefas, gerando fator de ruptura e, consequentemente, prejudicando a eficiência organizacional. Para Vandenberg (1999), a perda de colaboradores valiosos é considerada como um índice negativo de eficácia organizacional.

Os estudos de Ramlall (2003) comprovam os argumentos de Robbins (2002) e Vandenberg (1999). Segundo ele, o custo total da rotatividade gira em torno de $150 \%$ do salário de um bom empregado. O autor chama atenção para o fato de que a rotatividade excessiva prejudica o alcance dos objetivos organizacionais, gerando impactos negativos sobre a inovação, a qualidade, a consistência e o tempo de fornecimento de serviços aos clientes, além de ter 
como consequência perda do conhecimento que é levado com o empregado desligado.

Considerando que a rotatividade voluntária pode levar a saída de funcionários estratégicos, gerando prejuízo ao funcionamento organizacional, serão abordados no próximo tópico os modelos que procuram definir as prováveis causas que levam a este tipo de demissão, bem como as consequências a nível individual e organizacional.

\subsection{1.}

\section{Causas da Rotatividade}

O conceito da rotatividade é de fácil entendimento, contudo, entender os fenômenos que compõem a rotatividade é uma tarefa de grande complexidade analítica, devido à correlação de variáveis organizacionais, ambientais e individuais (DIEESE, 2011).

Diante disso, destacam-se dois grupos de pesquisa dedicados ao estudo da rotatividade. De um lado, observa-se o desenvolvimento de pesquisas no campo da Teoria Econômica, que associa a rotatividade a fenômenos econômicos e conjunturais, cujo objeto de estudo é o mercado de trabalho (MORRELL et al., 2001; CHAHAD, 2006).

A principal crítica aos modelos de rotatividade baseados na Teoria Econômica é a ausência de variáveis não monetárias para a explicação do fenômeno da rotatividade (RIBEIRO, 2001; HAUSKNECHT \& HOLWERDA, 2013).

De outro lado, destacam-se pesquisas no campo da Psicologia e Sociologia, que associam a rotatividade a fenômenos inerentes ao indivíduo, adotando o indivíduo e/ou a organização como objetos de estudo (HAUSKNECHT \& HOLWERDA, 2013).

Pesquisadores como Price (1977), Steers e Mowday (1981) e Mobley (1992) são autores seminais dessa segunda vertente e esboçaram modelos para o fenômeno da rotatividade de pessoal, com o objetivo de compreender profundamente o fenômeno da rotatividade, procurando esclarecer relações e conceitos; além de estimular a realização de novas pesquisas.

Em 1977, Price propôs um modelo estruturado sob a perspectiva sociológica, contudo não deixou de lado variáveis econômicas, tais como salário e oportunidade de crescimento. Ao trabalhar diferentes abordagens em um mesmo modelo, o autor analisa a rotatividade de forma mais ampla, apontando 
variáveis relacionadas ao indivíduo, à organização a ao mercado de trabalho (PRICE, 1977).

Price elege quatro determinantes principais da rotatividade voluntária, quais sejam: o salário pago aos trabalhadores, o nível de integração do trabalhador com os colegas, o nível de comunicação entre a empresa e os trabalhadores e o grau de centralização do poder (PRICE, 1977).

O modelo indica que o salário é inversamente proporcional à rotatividade, quanto menor o salário recebido pelo trabalhador, maior será a rotatividade. Em relação à integração do trabalhador com os demais colegas de trabalho, o autor afirma que a rotatividade é maior em relações em que há pouco ou nenhum vínculo afetivo. Outro aspecto que interfere positivamente na rotatividade de pessoas é o quanto a empresa transfere informações formais aos trabalhadores. Finalmente, o modelo aponta a centralização do poder como um aspecto negativo para a rotatividade, onde empresas muito centralizadas tendem a apresentar uma maior rotatividade quando comparadas àquelas mais descentralizadas (PRICE, 1977).

O modelo também aponta que a satisfação do trabalhador e as oportunidades oferecidas pelo mercado de trabalho são variáveis que mediam a relação entre as quatro determinantes citadas acima e a rotatividade. Ou seja, através da satisfação é possível compreender de que maneira as quatro determinantes afetam a rotatividade. Por exemplo, um salário elevado gera uma alta satisfação do trabalhador, reduzindo a rotatividade. A segunda variável interveniente, oportunidades oferecidas pelo mercado de trabalho, é independente em relação às quatro determinantes, já que se trata de um fator externo à empresa (PRICE, 1977).

O autor analisa a relação entre satisfação, oportunidade e rotatividade da seguinte forma: o trabalhador insatisfeito provavelmente deixará a empresa mediante outra oferta de emprego. Contudo, não se verifica alteração na rotatividade se o trabalhador insatisfeito observar que não existem oportunidades no mercado de trabalho (PRICE, 1977).

O autor concluiu que a rotatividade pode prejudicar a produtividade da organização, através da baixa satisfação ou pelos custos decorrentes da substituição de empregados, por outro lado pode maximizá-la, através do aumento da capacidade de inovação com a entrada de novos empregados, necessitando, portanto, ser melhor estudada nesse aspecto (PRICE, 1977).

Com o modelo denominado "Ligações Intermediárias", Mobley indicou a existência de outras variáveis, além das propostas por Price (1977), na relação 
entre rotatividade e satisfação. O modelo aponta que o fator determinante para a decisão de um indivíduo sair de um emprego é a satisfação e atração pelo trabalho desempenhado, de forma que a intenção de sair é a preditora imediata da rotatividade (MOBLEY, 1992).

Já Steers e Mowday expuseram um modelo mais complexo, formado por três eixos, quais sejam: expectativas e atitudes relativas ao trabalho; atitudes relativas ao trabalho e intenção de sair; e intenção de sair e possibilidade de recolocação no mercado de trabalho, sendo essa última a principal desencadeadora da rotatividade voluntária (LEE \& MOWDAY, 1987).

Enquanto no modelo proposto por Mobley a busca por outras oportunidades no mercado de trabalho antecede a intenção de sair, no modelo de Steers e Mowday a busca por alternativas disponíveis de trabalho é conseqüência da intenção de sair do trabalhador (LEE \& MOWDAY, 1987).

Assim como Price (1977) e Mobley (1992), outros autores também avaliam a satisfação no trabalho também pode ser considerada como um dos motivos para a rotatividade nas organizações. De acordo com a definição de Lee (2000, p.45), satisfação no trabalho é "um prazeroso estado emocional resultante da avaliação de um trabalho ou experiência no trabalho". Tamayo (1998) cita alguns fatores utilizados na mensuração de satisfação no trabalho: satisfação com a natureza do trabalho, satisfação com o salário, satisfação com o sistema de promoções, satisfação com os colegas e satisfação com os gerentes.

Tett e Meyer (1993), por sua vez, afirmam que o comprometimento com a organização é um dos principais antecedentes que podem desencadear 0 processo de desligamento, de maneira que os funcionários que estão fortemente empenhados são aqueles que são menos propensos a deixar a organização, além de apresentarem poucas faltas, melhor desempenho e maior produtividade. No mesmo sentido, Wright e Kehoe (2009) apontam que a intenção de permanecer numa determinada organização tem relação direta entre as práticas exercidas pela empresa para a gestão de pessoas, em que as práticas gerenciais de alto nível podem gerar um compromisso afetivo e influenciar nos índices de rotatividade.

Ramlall (2003) desenvolveu um estudo com o objetivo de identificar os fatores mais significativos que influenciam na decisão do empregado em permanecer numa organização e possíveis razões para deixar essa organização. Os resultados mostraram que as principais razões que levam um trabalhador a permanecer na empresa são: localização da organização, salários competitivos, a natureza do trabalho, a reputação da empresa, desenvolvimento de carreira, 
segurança no trabalho, cultura organizacional, os desafios, treinamento e desenvolvimento, poder e liberdade para tomada de decisão, benefícios atrativos e outros. Já os fatores potenciais que levam o indivíduo a deixar a empresa são: salário abaixo do mercado, poucos desafios e oportunidades de crescimento, impossibilidade de crescimento da carreira, pouco reconhecimento, liderança ineficaz, ambiente de trabalho, pouca estrutura de trabalho, falta de oportunidade para aprender novas tarefas e desenvolver novas habilidades.

As conclusões de Ramlall (2003) sinalizaram que a empresa precisava identificar e reter seus empregados críticos, entendendo as necessidades deles no que diz respeito à carreira, família, educação e convívio social. Além disso, precisava continuamente identificar suas necessidades e expectativas, diminuindo, assim, a probabilidade de perder os trabalhos críticos e comprometer os objetivos e resultados organizacionais.

Segundo Spector (2002), os motivos que podem desencadear um processo de desligamento do trabalhador tendem a estar associados ao desempenho inadequado, ao assédio de outras empresas sobre os bons empregados, à perseguição dos supervisores, às condições de trabalho e da empresa que são pouco atrativas. Estas condições provocam o desinteresse do trabalhador, aumentando a probabilidade de deixarem seus empregos. Outro aspecto que influencia no desligamento é a incompatibilidade do cargo com o perfil do ocupante (que pode estar aquém ou além de suas competências e expectativas).

Ainda de acordo com Spector (2002), a taxa de desemprego pode ser considerada não apenas uma causa, mas também um moderador de rotatividade, ou seja, havendo a possibilidade de obter outro emprego no mercado, o trabalhador se arriscará mais facilmente a pedir ou provocar a sua demissão.

\subsection{2.}

\section{Consequências da Rotatividade}

De acordo com Mobley (1992), o processo de rotatividade de pessoal dentro de uma organização apresenta aspectos positivos e negativos. Os pontos positivos são: afastamento de empregados não qualificados, inserção de novas pessoas inovando práticas da organização, maiores oportunidades de mobilidade interna e oportunidade de redução de custos e de conflitos enraizados. Por outro lado, o autor argumenta que a rotatividade voluntária implica em pelo menos três consequências negativas para as organizações: 
potenciais custos, perda de recursos humanos, e paralisação de atividades em execução. Existe ainda uma terceira corrente cuja visão a respeito da rotatividade é parcial, esse grupo trabalha com a ideia de que os custos da rotatividade são consequência de um processo da própria organização, a qual pode ou não se beneficiar do fenômeno (HOLLENBECK \& WILLIAMS, 1986).

As teorias do capital humano e social sugerem que a rotatividade, seja alta ou baixa, traz consequências negativas ao desempenho da organização. Segundo a teoria do capital humano, a performance individual está diretamente ligada ao tempo de permanência do trabalhador em determinada empresa, em função do acúmulo de conhecimentos acerca das atividades por ele desenvolvidas. Da mesma maneira, a empresa sofre uma perda substancial do capital humano quando o trabalhador sai, e o novo trabalhador que irá substituílo necessitará de longo tempo para alcançar o seu nível de conhecimento (PARK \& SHAW, 2013).

Na mesma linha da teoria do capital humano, a teoria do capital social entende que as relações sociais, como os objetivos coletivos e a confiança compartilhada, são negativamente impactados pela rotatividade; além de gerar custos elevados com a socialização do funcionário recém-chegado (PARK \& SHAW, 2013).

Gonzaga (1998) aponta que as organizações podem ser desestimuladas a investir em treinamento e desenvolvimento em função da rotatividade, uma vez que o tempo de permanência do funcionário na firma é reduzido. A consequência desse movimento é a redução da produtividade e uma perpetuação de baixa remuneração, além de baixa qualificação.

Mintzberg e Lampel (1999) reiteram que a rotatividade de funcionários pode exercer grande influência negativa nas organizações, em função de custos diretos com admissões e desligamentos, gastos com setor de recrutamento e seleção, perda de produtividade e de lucratividade, sobrecarga de funcionários que admitem temporariamente as funções do colega que saiu e impacta na motivação e comprometimentos dos funcionários que permanecem, podendo ainda, interferir na credibilidade junto aos clientes e na imagem da organização.

Oliveira (2004) destaca também que a alta rotatividade promove graves implicações para as empresas, como dificuldades de formação de equipes, ocorrência de relações interpessoais fracas e baixa integração com a cultura da empresa. Já Davis e Newstrom (1996) alegam que os empregados que ficaram na organização podem se sentir abalados pela perda do colega de trabalho. Robbins (2002), por sua vez, afirma que a rotatividade voluntária normalmente 
implica perda de pessoas estratégicas, e como consequência deste fator de ruptura há um prejuízo na eficiência organizacional.

O custo com a rotatividade de pessoal, segundo Cascio (1991), muitas vezes não é conhecido pela organização e, por isso, não é controlado. No entanto, uma vez que se conhece os custos envolvidos e o impacto no gerenciamento do negócio, deve-se determinar quais destes custos são razoavelmente controláveis e focar a atenção neles, visando reduzi-los.

Analisando a vertente que trata a rotatividade como algo positivo, pesquisadores como Dalton e Todor (1982) afirmam que a manter as taxas de rotatividade dentro de níveis razoáveis é fundamental para economizar quantias consideráveis em dinheiro. Para esses autores, isso é possível porque é economicamente mais interessante realizar novas contratações do que manter funcionários através de altos salários e benefícios. O grande problema é determinar qual a taxa de rotatividade ótima para determinada organização.

Ainda de acordo com Daltan e Todor (1982), a rotatividade contribui para o desenvolvimento da inovação dentro das organizações. A entrada de novos funcionários é uma maneira de reciclar a companhia, tornando-a capaz de adaptar-se às demandas internas e externas. Além disso, os indivíduos que apresentam baixo desempenho na organização possuem maior propensão a saírem voluntariamente do emprego, devido à baixa perspectiva de crescimento e à redução da segurança no emprego. Sob essa ótica, pessoas com melhor desempenho passam a ser selecionadas para fazer parte do quadro de funcionários quando a organização atinge um nível de rotatividade ótimo, levando a uma maior produtividade na empresa.

As consequências positivas da rotatividade podem ainda atingir o nível individual. Uma pesquisa realizada por Davia (2005) aponta que trabalhadores que optaram por trocar de emprego ainda no início da carreira, conseguem aumentos de salário mais consideráveis do que aqueles funcionários que permanecem por muito tempo num mesmo emprego. Além disso, a mobilidade de um emprego para o outro faz com que o trabalhador conheça melhor as suas capacidades, aumentando a sua maior produtividade e, consequentemente, obtendo salários mais altos (ARRANZ \& DAVIA, 2010).

Já o terceiro aspecto relacionado às consequências da rotatividade para as organizações - a visão parcial - é defendido por Abelson e Baysinger (1984) e Bluedorn (1978). De acordo com estes autores, é preciso ir além do conceito de rotatividade funcional e disfuncional e compreender de que maneira os principais atributos individuais, organizacionais e ambientais afetam os mais diversos 
custos e benefícios associados à rotatividade de funcionários de alto desempenho.

Para Abelson e Baysinger (1984), a saída de um trabalhador de uma empresa é considerada disfuncional desde que resulte em redução do desempenho organizacional, medida através de indicadores financeiros, da sua participação no mercado, queda na quantidade e qualidade da mão-de-obra, falta de esclarecimento quanto à situação e propósito da organização tanto para o público interno quanto para o externo, dentre outros fatores.

Além disso, é importante entender que essa saída gera custos agregados, tais como os gastos com demissão e custos com treinamentos de novos funcionários. Contudo, a empresa assumirá os custos de retenção desse trabalhador, como salários e benefícios muitas vezes superiores, caso opte pela manutenção desse trabalhador (ABELSON \& BAYSINGER, 1984).

A tese defendida pelos autores é que a empresa deve encontrar qual é a sua taxa de rotatividade ótima, que é alcançada quando os custos relacionados com a retenção de funcionários considerados de alto valor agregado anulam os custos de rotatividade, deste modo, é saudável para a empresa ter uma taxa positiva de rotatividade (ABELSON \& BAYSINGER, 1984).

Em suma, a rotação de pessoal, quando em níveis elevados, torna-se uma preocupação para a organização, devido aos seus numerosos aspectos negativos. A médio e longo prazo, o turnover ocasiona grandes prejuízos à empresa, ao mercado, à economia como um todo e principalmente aos funcionários.

\subsection{3.}

\section{Intenção de Rotatividade}

Steers e Mowday (1981) definem a intenção de rotatividade como uma probabilidade subjetiva, própria dos indivíduos, de deixar a organização em algum ponto do futuro próximo, de tal maneira que o simples desejo configura o que se chama intenção de rotatividade.

A importância do estudo da intenção de rotatividade na investigação da rotatividade de pessoal reside no fato de a intenção ser considerada uma variável cognitiva final que pode afetar diretamente o desligamento efetivo (CHANG, 1999). Ressalta-se que tanto as pesquisas acadêmicas quanto as experiências corporativas sugerem uma forte relação entre funcionários que expressam intenção de sair e aqueles que realmente deixam a organização 
(MOBLEY, 1992; TETT \& MEYER, 1993; PHILLIPS \& CONNEL, 2003; WINTERTON, 2004).

Corroborando as proposições acima, Mobley (1992) também destaca que as intenções de rotatividade podem preceder um desligamento efetivo. Para este autor, a estimativa periódica das intenções de comportamento de saída constitui uma abordagem bastante recomendada para as organizações. Ou seja, faz-se necessário buscar alternativas que possibilitem a realização de um diagnóstico, bem como uma avaliação das prováveis causas que levariam um empregado com bom desempenho a tomar a decisão de deixar a organização em que trabalha a fim de se adotar cursos de ação e políticas para evitar a evasão voluntária.

Souza-Poza e Henneberger (2004) realizaram um estudo comparativo sobre intenção de rotatividade envolvendo vinte e cinco países. Os autores concluíram que importantes condicionantes e/ou determinantes da intenção de rotatividade são de natureza subjetiva, tais como: satisfação e segurança no trabalho, oportunidade de crescimento na empresa e orgulho pela tarefa que desempenha no cargo. Além disso, outras variáveis objetivas foram analisadas, tais como gênero, idade, família e salário.

Com relação ao gênero, Souza-Poza e Henneberger (2004) apontam que as mulheres apresentam uma maior tendência a se manterem no emprego em relação aos homens. No que tange à idade, existe uma relação inversa com a intenção de rotatividade, ou seja, quanto maior a idade menos atraente se torna a mudança de emprego. Além disso, a formação de uma família também influencia negativamente na rotatividade, provavelmente em função dos custos envolvidos com a mudança de todos os membros. Finalmente, os autores afirmam que quanto mais alto o valor do salário, menor a chance de troca de emprego, visto que as possibilidades de encontrar uma organização que pague mais são menores. Outros benefícios indiretos também tendem a reduzir a intenção de rotatividade, como horário flexível de trabalho, expectativa de promoção, capacitação contínua e tamanho da empresa.

Siqueira e Pereira (2001 e 2005), por sua vez, desenvolveram um estudo a fim de testar um modelo para intenção de rotatividade, a partir da sua relação com comprometimento organizacional, satisfação no trabalho e percepção de justiça de remuneração. Os resultados deste estudo evidenciaram que se o indivíduo percebe justiça na remuneração que recebe, está satisfeito com o trabalho e comprometido afetivamente com a empresa, há uma tendência em reduzir sua intenção de sair da empresa onde trabalha. Assim, foi constatado 
que as três variáveis se correlacionam negativamente com intenção de rotatividade.

Outras pesquisas sobre a intenção do indivíduo em deixar a organização envolvem variáveis do comportamento organizacional, quer sejam elas do nível micro organizacional (características individual, de personalidade, satisfação, autoestima, etc), do nível meso organizacional (relações interpessoais, trabalho em equipe, papéis, etc) ou do nível macro organizacional (cultura, clima, liderança, produtividade, rotatividade, etc).

Finalmente, Wright e Kehoe (2009) apontam que a intenção de permanecer numa determinada organização tem relação direta entre as práticas exercidas pela empresa para a gestão de pessoas, em que as práticas gerenciais de alto nível podem gerar um compromisso afetivo e influenciar nos índices de rotatividade da organização.

\subsection{4.}

Taxa de Rotatividade

Segundo Pontes (2001), a rotatividade é utilizada para avaliar o mercado de trabalho. Para tanto, esse indicador é apurado através de percentuais e geralmente é calculado mensalmente.

O cálculo mais utilizado na literatura nacional para a rotatividade leva em conta o valor mínimo observado entre o total de admissões e o total de desligamentos anuais, comparado ao estoque médio de cada ano. Em um mercado de trabalho de ciclo expansivo, as admissões serão superiores aos desligamentos, e o montante destes é indicativo da necessidade de substituição e mão de obra. Se, por outro lado, em um mercado de trabalho de ciclo de contração, os desligamentos serão superiores às admissões, logo, toma-se o volume destas no cálculo (DIEESE, 2011; DIEESE, 2014).

Tal cálculo pode ser realizado a partir do total dos desligados na apuração do menor valor observado entre desligados e admitidos, ou seja, trata-se do cálculo para o conjunto do mercado de trabalho. Pode-se também excluir os desligamentos decorrentes de falecimento, aposentadoria, transferência e iniciativa do trabalhador, chegando-se à taxa de rotatividade descontada (DIEESE, 2014).

De acordo com Pontes (2011), a fórmula mais difundida entre as empresas para cálculo da rotatividade é a seguinte: 


$$
I R=\frac{\frac{(A+D)}{2} * 100}{E M}
$$

Onde:

- $\mathrm{A}=$ Admissões de pessoal dentro do período considerado (entradas);

- $\mathrm{D}=$ Desligamentos de pessoal (tanto por iniciativa da empresa como por iniciativa dos empregados) dentro do período considerado (saídas);

- $\quad E M=$ Efetivo médio dentro do período considerado. Pode ser obtido pela soma dos efetivos existentes no início e no final do período, dividido por dois.

No entanto, a não ser que tenha havido demissões sem reposição imediata, observa-se que o índice final não se altera ao longo do período maior, e porque também é prática no mercado não levar em conta as demissões que ocorreram por redução de atividades da empresa ou por motivos de conjuntura econômica.

Segundo Pontes (2001), Para verificar as perdas e suas causas, não se consideram as admissões no cômputo do índice de rotatividade de pessoal, mas somente os desligamentos, sejam por iniciativa da organização ou dos empregados. Utiliza-se a seguinte fórmula:

$$
I R=\frac{D * 100}{E M}
$$

Onde:

- $\mathrm{D}=$ Desligamentos de pessoal (tanto por iniciativa da empresa como por iniciativa dos empregados) dentro do período considerado (saídas);

- $\mathrm{EM}=$ Efetivo médio dentro do período considerado. Pode ser obtido pela soma dos efetivos existentes no início e no final do período, dividido por dois.

No Brasil, as informações relacionadas às taxas de rotatividade são baseadas em dados secundários, coletados principalmente pelo Instituto Brasileiro de Geografia e Estatística (IBGE) e Ministério do Trabalho e Emprego 
(MTE) o qual possui como principal base de dados a Relação Anual de Informações Sociais (RAIS) e o Cadastro Geral de Empregados e Desempregados (CAGED) (GONZAGA, 1998).

As empresas são obrigadas por determinação legal a informar mensalmente a movimentação realizada em termos de admissões e desligamentos ao Ministério do Trabalho e Emprego, por meio do CAGED. Já os registros anuais de toda essa movimentação são informados por meio da RAIS, que permite identificar o volume e as principais características dos contratos de trabalho no mercado formal, bem como a movimentação relacionada às admissões e desligamentos (DIEESE, 2011).

Apesar das fontes citadas acima serem fundamentais para 0 desenvolvimento do estudo da rotatividade e do mercado de trabalho de uma maneira geral, levam em conta somente o mercado de trabalho formal, sendo que cerca de $44 \%$ da força de trabalho do país é informal e ficam de fora dessas análises estatísticas (DIEESE, 2014).

\subsection{5. \\ Mercado de Trabalho e Rotatividade no Brasil}

A flexibilidade contratual pode ser considerada uma das características mais emblemáticas do mercado de trabalho formal brasileiro, o que acaba facilitando tanto os desligamentos quanto as admissões. Outro aspecto a ser destacado é o fato de a dispensa poder ser realizada sem justa causa, sem a necessidade de autorizações ou requisitos. Tais características, somadas à oferta crescente de postos de trabalho, tende a aumentar ainda mais as taxas de rotatividade (DIEESE, 2011).

Um dado que comprova essa realidade diz respeito ao acréscimo de $65 \%$ no estoque anual de contratos de trabalho da RAIS quando se compara o resultado de 2002 com o resultado de 2012, isso representa 18,8 milhões de contratos de trabalho. Em relação aos desligamentos, os números apontados indicam o acréscimo de 13,6 milhões de contratos de trabalho rompidos, ou seja, um crescimento de $111,3 \%$ de 2002 para 2012 (DIEESE, 2014).

É comum na literatura brasileira a associação das elevadas taxas de rotatividade ao contexto institucional que regula o mercado de trabalho no Brasil. Segundo esses pesquisadores, os benefícios aos quais os funcionários com carteira assinada têm direito após o desligamento de uma empresa, tais como seguro desemprego e o fundo de garantia por tempo de serviço (FGTS), atuam 
como catalizadores da ruptura do vínculo empregatício (GONZAGA, 1998; DIEESE, 2011).

Gonzaga (1998) ainda aponta que a legislação trabalhista brasileira impulsiona também a rotatividade promovida pelas empresas em períodos de baixo faturamento, uma vez que não dispõe de mecanismos como benefícios para emprego em tempo parcial ou regras mais flexíveis para os turnos diários de trabalho, entre outros.

Por outro lado, destaca-se a redução da taxa de desemprego na economia brasileira desde o início dos anos 2000 - passando de 12,6\% da força de trabalho em 2002 para 5,4\% em 2013. Ainda assim, observa-se também grande elevação dos gastos públicos com o pagamento de seguro desemprego, motivado pela combinação do aumento de empregos formais, com o número maior de trabalhadores com acesso ao benefício, associado à elevação da taxa de rotatividade da mão-de-obra e ao crescimento do salário mínimo nos últimos anos.

O principal motivo de desligamento no Brasil é a demissão sem justa causa, sendo a responsável por $46,3 \%$ dos desligamentos em 2012. Embora em menor proporção, a demissão voluntária apresentou crescimento, passando a representar $25 \%$ do total das demissões em 2012, contra $15,8 \%$ em 2002 , ou seja, teve crescimento de $9,2 \%$ nesse período. Já o término do contrato se manteve constante nesse período, sendo responsável por cerca de $20 \%$ dos desligamentos. Finalmente, as demissões relacionadas às transferências, aposentadorias e falecimentos mantiveram-se constante entre os anos de 2002 e 2012, representando cerca de 7\% do total (DIEESE, 2014).

A rotatividade atinge mais aqueles trabalhadores de baixa escolaridade, de forma que, a probabilidade de o empregado permanecer no emprego é maior nos postos de trabalho que exigem maior nível de instrução. Com relação à faixa salarial, pode-se afirmar que o formato é muito semelhante ao do nível de instrução (DIEESE, 2014).

O DIEESE (2014) elaborou um ranking das 20 famílias ocupacionais que mais demitiram entre os anos de 2005 a 2012 - responsáveis por cerca de 54\% do total de desligamentos - com o objetivo de compreender melhor as características dos desligamentos realizados no mercado de trabalho brasileiro. A família "motoristas de veículos de cargas em geral", da qual faz parte o público alvo do presente estudo ocupa a nona posição no ranking de 2011 e 2012, sendo responsável por $2,1 \%$ do total de desligamentos. 
$\mathrm{Na}$ base de dados da RAIS, os dados demonstram que há um conjunto pequeno de estabelecimentos responsáveis por grande parte dos desligamentos e, consequentemente, pela rotatividade observada no mercado de trabalho brasileiro. Em 2011 e 2012, 96\% das empresas brasileiras fizeram até 25 desligamentos e foram responsáveis por $36 \%$ do total de desligamentos nestes anos, enquanto 4\% das empresas que desligaram mais de 25 vínculos responsabilizaram-se por cerca de $64 \%$ dos desligamentos no mercado de trabalho formal (DIEESE, 2014).

Diante do exposto, verifica-se a possibilidade de alcançar uma redução expressiva das taxas de rotatividade, mediante alterações no sistema público, por meio da implantação de novas políticas para o mercado de trabalho, e no sistema privado, via revisão das práticas e procedimentos adotados por cada empresa (DIEESE, 2014).

É fato que o Brasil vivenciou um processo de desenvolvimento econômico bastante significativo na última década, caracterizado também por uma distribuição de renda para as classes mais pobres, por meio de políticas distributivas, geração de emprego formal, valorização do salário mínimo, ampliação das políticas sociais, entre outras iniciativas e políticas públicas. Contudo, as políticas públicas voltadas para o mercado de trabalho ainda são incipientes, indo de encontro à concepção de desenvolvimento pautado pelo protagonismo do trabalho na vida das pessoas e na economia (DIEESE, 2014).

Diante do exposto, é imprescindível a reestruturação do sistema de políticas públicas para o mercado de trabalho. É importante que aspectos importantes sejam revistos, quais sejam: vínculos mais estáveis nos contratos de trabalho, proteção mais adequada diante do infortúnio do desemprego, incluindo serviços públicos de intermediação de mão de obra de melhor qualidade, o aperfeiçoamento da concepção da promoção, proteção ampla do emprego, a criação de um serviço de orientação vocacional, especialmente para aqueles que procuram o primeiro emprego. (DIEESE, 2014).

Seria plausível também a utilização da negociação coletiva como instrumento para elevar o padrão regulatório das condições de trabalho. Com a essa flexibilização dos direitos trabalhistas, os únicos atores do processo de negociação seriam a empresa e o sindicato dos trabalhadores. O objetivo é que os trabalhadores possuam uma representação sindical ativa na empresa para expressar seus descontentamentos, permanecendo no emprego por um longo período e, portanto, reduzindo a rotatividade voluntária (GONZAGA, 1998; DIEESE, 2014). 
Outro ponto importante que precisa ser discutido pela sociedade diz respeito a reformulação das leis trabalhistas do país. A desvinculação da retirada do saldo do FGTS da saída do funcionário da empresa reduziria o incentivo ao trabalhador para que este seja demitido. O objetivo de tal mudança é fazer com que a perda do emprego formal fosse vista como algo ruim, e, portanto, a ser evitado pelo trabalhador. Contudo, é muito pouco provável que tal medida seja colocada em prática, uma vez que se trata de uma questão extremamente impopular (GONZAGA, 1998).

\section{3.}

\section{Absenteísmo}

Existem definições conflitantes quanto ao termo absenteísmo. Harrison e Martocchio (1998) entendem absenteísmo como o ato de "faltas a um compromisso de trabalho". Esta definição, porém, engloba toda e qualquer forma de não comparecimento ao trabalho, ainda que seja direito do trabalhador, como licença médica ou luto. Dias (2006) afirma que os períodos programados de ausência, como licença e férias, devem ser entendidos como absenteísmo. Estes autores entendem o absenteísmo do ponto de vista organizacional, pois os gestores precisam lidar com todas as ausências da mesma forma, incluindo no seu planejamento ausências previstas ou não.

Para a Organização Internacional do Trabalho - OIT (1999), é a ausência remunerada ou não do trabalhador por mais de um dia de trabalho quando se esperava que ele estivesse presente, seja por ordem médica ou qualquer outra. Para a OIT, as ausências podem ser previstas como férias, folgas e feriados, parcialmente previstas como maternidade, paternidade e outras licenças amparadas por lei (jurado, mesário, etc) ou não previstas, que efetivamente caracterizam o absenteísmo, como licenças médicas, acidente de trabalho, luto. Essa definição será utilizada como base para este estudo, uma vez que tem a preocupação de abarcar as faltas por motivos de saúde.

Seguindo a mesma linha, Johns (2003) diz que absenteísmo corresponde ao "número de faltas não programadas em dado período". Essa definição será utilizada como base para este estudo, uma vez que tem a preocupação de abarcar as faltas por motivos de saúde.

Os autores defendem diversas faces do absenteísmo, como Brief (2002), que apontou baixa correlação entre o constructo e atitudes no trabalho. Segundo o autor isso foi verificado devidas às inúmeras causas do absenteísmo, embora Ihe pareça lógico que alguém que não esteja muito satisfeito com seu trabalho 
esteja menos propenso a ser assíduo. O autor sugere que seja construída uma tipologia do construto que observe, por exemplo, as formas voluntárias e involuntárias de ausências do trabalho programado, no nível individual.

Outros autores, como Dalton e Mesch (1991), defendem tipologias para o construto, ao realizarem a distinção entre absenteísmo devido a doenças ou devido a outras circunstâncias. Os autores encontraram correlações significativas entre variáveis do nível micro-organizacional (satisfação e gênero) e absenteísmo involuntário e, por outro lado, ausências por outras circunstâncias relacionadas a variáveis do nível macro-organizacional (estabilidade do emprego e políticas organizacionais).

McDonald e Shaver (1981) propõem uma tipologia estabelecida em três categorias de absenteísmo, baseados em causas intrínsecas (como eficiência da supervisão, características do cargo e controle), causas extrínsecas (como políticas organizacionais sobre absenteísmo, comunicação, condições de trabalho) e causas de personalidade (inclusive alcoolismo).

Seguindo a discussão sobre as diferentes formas de absenteísmo, Steel (2003) analisou as metodologias utilizadas, e ressaltou a diferenciação mais aceita entre os tipos de ausências do trabalho: voluntárias ou involuntárias. Nesse modelo, foi feita uma diferenciação entre absenteísmo involuntário, medido em função do tempo total perdido (somatório de dias ou horas, onde pesam mais as ausências prolongadas, como as doenças), e absenteísmo voluntário, medido em função da frequência do comportamento (onde são ressaltadas as ausências repetidas).

Baseado nesta distinção de absenteísmo voluntário e involuntário, Steel (2003) comparou os resultados de três análises sobre absenteísmo e satisfação no trabalho, variável correlacionada às ausências voluntárias. Os resultados indicaram que não há suporte empírico para esta distinção entre absenteísmo voluntário (frequência) e involuntário (tempo perdido). Sendo assim, a indicação de Brief (2002) para a construção de um modelo que analisasse separadamente o absenteísmo voluntário e involuntário e sua relação com satisfação no trabalho, demonstra-se insuficiente para explicar a inconsistência de resultados ligando atitudes ao absenteísmo (DIAS, 2006).

\subsection{1.}

\section{Características Relevantes para o Absenteísmo}

De acordo com Harrison e Martocchio (1998), as origens do absenteísmo podem ser classificadas em curto, médio e longo prazo, dividindo as principais 
causas em períodos de um a três meses, de quatro meses a um ano, e acima de um ano, respectivamente. As variáveis de curto prazo se referem principalmente a problemas de tomada de decisão; as de médio prazo são relacionadas a atitudes e contexto social; finalmente, as de longo prazo incluem personalidade e características demográficas.

Em relação às origens de curto prazo, a pesquisa de Harrison e Martocchio (1998) identificaram avanços das empresas quanto aos fatores mais apontados pelos empregados para justificar suas ausências: dores, resfriados e gripes, e problemas de saúde de familiares, que têm se mostrado suscetíveis a intervenções, como vacinação contra gripes que reduzem em até $43 \%$ as ausências relacionadas a esse motivo.

Quanto as medidas de médio prazo, a pesquisa encontrou resultados interessantes também para as práticas organizacionais de Recursos Humanos, que conseguem diminuir os níveis de ausência com a adoção de horário flexível e permissões para a troca de turno entre os empregados. Outros registros também foram observados, como a influência de variáveis macroeconômicas (relação inversa entre absenteísmo e desemprego), características do trabalho e stress relacionado ao trabalho (HARRISON \& MARTOCCHIO, 1998).

Já as influências de longo prazo sobre o absenteísmo têm sido vistas geralmente em função de características de personalidades, variáveis demográficas e problemas crônicos de saúde e hábitos individuais. Entre as variáveis demográficas, Harrison e Martocchio (1998) apontam idade e gênero como as mais investigadas.

De maneira geral, Johns (2003) entende que o absenteísmo não é apenas um, mas uma grande variedade de comportamentos, com diversas causas, podendo-se citar: doença, atrasos involuntários, faltas voluntárias por motivos pessoais, dificuldades e problemas financeiros, problemas de transporte, baixa motivação, supervisão precária, políticas inadequadas da organização, dentre outros. Assim, Oliveira (2004) especifica que estes motivos podem ser de natureza pessoal, ambiental, social, familiar, financeira, e até mesmo, relacionados à estrutura organizacional - as causas do absenteísmo não estão necessariamente no trabalhador, mas, na organização, principalmente quando há uma supervisão deficiente, tarefas repetitivas, desmotivação e ambiente de trabalho desfavorável.

Johnson e O'Leary (2003), por sua vez, afirmam que a presença ao trabalho deve ser vista como um conjunto integrado de motivos. Dentre eles, destacam-se os fatores biográficos como gênero, idade e educação. Segundo 
Chaudhury e NG (1992), com relação ao gênero, as mulheres possuem maior tendência em sair do trabalho por serem mais sensíveis aos acontecimentos que geram o absenteísmo, e também, devido as suas diversas responsabilidades familiares, especialmente como esposa e mãe, além dos cuidados que elas geralmente dispõem para a realização de atividades domésticas, onde exercem outra jornada de trabalho. Quanto à faixa etária, os mesmos autores relatam que trabalhadores com idades mais elevadas estão mais propensos a absterem-se do trabalho, devido a problemas de saúde.

No mesmo sentido, Robbins (1999) afirma que, em geral, empregados mais idosos possuem taxas mais baixas de faltas voluntárias do que os mais jovens. Entretanto, eles têm taxas mais altas de faltas involuntárias, possivelmente devido à problemas de saúde relacionados ao envelhecimento. Todavia há estudos que contradizem este relato, chegando a considerar a relação entre a idade e o absenteísmo indeterminada (MARIM, 2012).

Com relação à escolaridade, Chaudhury e NG (1992) afirmam que os trabalhadores com maior nível de escolaridade são menos propensos ao absenteísmo, visto que possuem maior autonomia e participação em seus trabalhos.

Com relação ao estado civil, Robbins (1999) afirma que os empregados casados tendem a faltar menos, pois o casamento impõe responsabilidades crescentes que podem tornar o emprego fixo mais valioso e importante, o autor complementa sugerindo o aprofundamento dessa questão.

Independente do motivo para a ausência do funcionário no trabalho, o fenômeno de abster-se sempre resultará em baixa produtividade e baixa qualidade de produtos e serviços (BERNSTORFF \& ROSSO, 2008).

\subsection{2.}

\section{Taxa de Absenteísmo}

Absenteísmo é uma palavra com origem no latim, onde absens significa "estar fora, afastado ou ausente". O absenteísmo consiste no ato de se abster de alguma atividade ou função. Referem-se ao absenteísmo como sendo: "A frequência e/ou duração do tempo perdido de trabalho, quando os empregados não vêm trabalhar [...]". (MILKOVICH \& BOUDREAU, 2000, p.123).

É por causa do impacto na força produtiva que as empresas se atentam a buscar soluções para corrigirem seus índices bem como para controlar os mesmos. Podendo adotar como método de cálculo ou controle do absenteísmo, a seguinte formula: 


$$
I A=\frac{D A}{E M^{*} D T}
$$

Onde:

- $D A=$ Dias de ausência no período;

- $E M=$ Efetivo médio dentro do período considerado. Pode ser obtido pela soma dos efetivos existentes no início e no final do período, dividido por dois.

- $D T=$ Quantidade de dias trabalhados do período considerado.

Essa formula reflete tanto a quantidade de empregados faltosos como a duração de sua ausência, não inclui as faltas abonadas por diferentes motivos, as licenças por doença depois dos primeiros quatro dias ou planejadas e autorizadas com antecedência. Os índices de absenteísmo podem ser acompanhados periodicamente, sendo, mensal, trimestral, semestral ou mesmo anuais.

O índice de absenteísmo proposto pela OIT (1999) recomenda a exclusão de férias e folgas do cálculo do absenteísmo por considera-las previsíveis e programáveis. Sendo, portanto, definição e indicadores considerados pertinentes no presente estudo. 


\section{3 \\ Metodologia}

Este capítulo descreve a metodologia adotada neste trabalho: o tipo de pesquisa realizado, os constructos mensurados, a delimitação da população estudada, o processo de amostragem, o método utilizado para coleta de dados, as técnicas e procedimentos empregados para o tratamento e a análise dos dados e as limitações do método.

\section{1. \\ Tipos de pesquisa (Design da Pesquisa)}

A tendência à classificação é uma característica da racionalidade humana. Ela possibilita melhor organização dos fatos e consequentemente seu entendimento. Assim, classificar as pesquisas torna-se uma atividade importante. À medida que se dispõe de um sistema de classificação, torna-se possível reconhecer as semelhanças e diferenças entre as diversas modalidades de pesquisa. Dessa forma, o pesquisador passa a dispor de mais elementos para decidir a cerca de sua aplicabilidade na solução dos problemas propostos para investigação. (GIL, 2010, p. 25)

De acordo com a conceituação proposta por Gil (2010), as pesquisas podem ser classificadas de acordo com três critérios fundamentais: (1) quanto à sua finalidade, (2) segundo seus objetivos mais gerais, e (3) em relação aos métodos empregados.

\subsection{1.}

\section{Classificação quanto à sua finalidade}

As pesquisas podem ser classificadas em duas grandes categorias quanto à sua finalidade. A primeira, denominada pesquisa básica, visa preencher uma lacuna existente no conhecimento. A segunda, denominada pesquisa aplicada, diz respeito aos estudos que objetivam solucionar problemas identificados nos ambientes sociais em que estão inseridos os pesquisadores.

De acordo com essa conceituação o presente estudo pode ser classificado, quanto à sua finalidade, como uma pesquisa aplicada. Ao analisar a 
influência da confiança organizacional nos índices de absenteísmo e rotatividade de duas organizações, pretende-se solucionar as questões inseridas no universo dessas empresas especificamente.

\subsection{2.}

\section{Classificação quanto aos objetivos mais gerais}

Segundo Gil (2010), em relação aos objetivos mais gerais, ou propósitos, as pesquisas tendem a ser classificadas em exploratórias, descritivas e explicativas.

As pesquisas exploratórias têm como objetivo facilitar uma maior familiaridade com o problema, buscando torná-lo mais explícito e possibilitar a formulação de hipóteses; as pesquisas descritivas buscam identificar relações entre as variáveis e levantar opiniões, atitudes e crenças de uma determinada população ou grupo, de forma que seja possível identificar suas características; já as pesquisas explicativas pretendem reconhecer e explicar detalhadamente as causas que antecedem os fenômenos (GIL, 2010).

Deste modo, o presente estudo pode ser classificado quanto aos objetivos mais gerais como exploratório e descritivo, já que pretende através de hipóteses, identificar possíveis relações entre o construto confiança e os índices de rotatividade e absenteísmo.

\subsection{3.}

\section{Classificação quanto aos métodos empregados}

A qualidade dos resultados de uma pesquisa está diretamente relacionada ao método empregado para a coleta de dados e aos procedimentos empregados em sua análise e interpretação. Assim, as pesquisas podem ser classificadas de acordo com a natureza dos dados, sendo denominadas como quantitativas ou qualitativas; ou podem ainda ser classificadas quanto ao ambiente em que os dados foram coletados, neste caso podem ser pesquisas de campo ou laboratório, etc (GIL, 2010).

Portanto, em relação aos métodos adotados, este estudo trata-se de uma pesquisa com abordagem qualitativa. $O$ instrumento de coleta de dados utilizado foi um formulário estruturado respondido por motoristas de ônibus das empresas pesquisadas.

Já em relação ao ambiente em que os dados foram coletados, o presente estudo pode ser classificado como uma pesquisa de campo. A estratégia de investigação empregada, por sua vez, foi o estudo de casos, dado que se trata 
de uma investigação empírica cujo objetivo é analisar o fenômeno em questão sob a perspectiva dos indivíduos nele envolvidos, considerando todos os pontos de vista relevantes (GODOY, 1995).

\section{2.}

\section{Questionário de Pesquisa}

A literatura apresenta diversos estudos direcionados à medição da confiança organizacional, destacando-se Organizational Trust Inventory - OTI (CUMMINGS \& BROWLLEY, 1996), Behavioral Trust Inventory - BTI (GILLESPIE, 2003), Organizational Trust Index - OTI (SHOCKLEY-ZALABACK et al. (2003) e Instrumento de Medida da Confiança (MCALLISTER, 1995).

Contudo, grande parte dos questionários utilizados para medição de confiança organizacional foi aplicada em empresas norte-americanas e validados fora do país, podendo levar a resultados com viés cultural, em função das diferenças culturais, estruturação dos questionários ou apresentação das questões.

Deste modo, optou-se por utilizar como instrumento de coleta de dados um questionário construído e validado cientificamente no Brasil: Escala de Confiança do Empregado na Organização - ECEO. Trata-se de uma medida multidimensional composta por cinco dimensões: promoção do crescimento do empregado, solidez organizacional, normas relativas à demissão de empregados, reconhecimento financeiro organizacional, e padrões éticos.

O instrumento apresenta duas versões: completa e reduzida. A opção pela versão reduzida (28 itens) deu-se em função da utilização das questões mais relevantes em cada dimensão, definidas a partir do cálculo dos índices de confiabilidade ( $\alpha$ de Cronbach). Além disso, a redução do número de itens não afetou negativamente a precisão da medida.

\subsection{1.}

\section{Escala de Confiança do Empregado na Organização (ECEO)}

O questionário ECEO elaborado por Aurea de Fatima Oliveira e Álvaro Tamayo tem por objetivo medir o quanto o colaborador acredita que pode confiar na organização em que trabalha.

A versão completa possui 47 questões, já a forma reduzida utilizada no presente estudo possui 28 itens. Em ambos os casos, a aplicação pode ocorrer de forma individual ou coletiva e os respondentes utilizam a escala de Likert de cinco pontos para indicar o seu nível de concordância com as questões (1- 
Discordo totalmente, 2- Discordo, 3- Nem concordo, nem discordo, 4- Concordo, 5- Concordo Totalmente). O cálculo do escore médio é obtido somando-se os valores indicados pelo respondente dentro dos parênteses e dividindo-se essa somatória pelo número de itens de cada fator. O valor obtido deverá situar-se entre um e cinco e a interpretação dos resultados obtidos deverá considerar que quanto maior for o escore médio, mais o respondente mostra sua concordância com o conteúdo avaliado por um dado fator. Deste modo, valores entre 4 e 5 são indicadores de concordância enquanto valores situados entre 1 e 2,9 revelam discordância. Os valores situados entre 3 e 3,9 tendem a mostrar indiferença do respondente (TAMAYO \& OLIVEIRA, 2008).

Para preservar as características da medida é necessário que as instruções, frases e escalas de respostas não sejam modificadas. $\mathrm{Na}$ tabela 1 , são apresentadas as denominações das dimensões e as questões as quais estão baseadas a escala. As questões que tiveram a escala invertida estão acompanhadas do símbolo *. 
Tabela 1: Dimensões da Confiança

\begin{tabular}{|c|c|c|c|c|c|c|c|}
\hline & & & ersão Comple & & & são Reduzida & \\
\hline Dimensão & Definição & $\mathbf{N} \circ$ Itens & Itens & $\begin{array}{c}\text { Índices de } \\
\text { Precisão }\end{array}$ & $\mathbf{N} \circ$ Itens & Itens & $\begin{array}{c}\text { Índices de } \\
\text { Precisão }\end{array}$ \\
\hline $\begin{array}{l}\text { Promoção do crescimento } \\
\text { do colaborador }\end{array}$ & \begin{tabular}{|l|} 
Incentivo ao crescimento profissional dos \\
colaboradores por meio de alternativas \\
concretas e reais propostas pela organização, \\
permitindo aos colaboradores prever seu \\
crescimento naquele contexto de trabalho.
\end{tabular} & 7 & $\begin{array}{c}33,11,45 \\
21,19,37 \\
22\end{array}$ & 0,92 & 5 & $\begin{array}{c}11,19,21 \\
33,45\end{array}$ & 0,9 \\
\hline Solidez organizacional & $\begin{array}{l}\text { Refere-se à firmeza, à estabilidade financeira } \\
\text { da organização cujos reflexos são o } \\
\text { cumprimento de suas obrigações financeiras } \\
\text { com os colaboradores, o pagamento de } \\
\text { salário pontualmente, a perspectiva de um } \\
\text { futuro próspero, bem como a capacidade de } \\
\text { superar crises econômicas ocasionadas por } \\
\text { planos governamentais e mudanças de } \\
\text { mercado. }\end{array}$ & 12 & $\begin{array}{c}2,4,8,17 \\
18,24,26 \\
29,30,34, \\
32,38\end{array}$ & 0,86 & 5 & $\begin{array}{c}8,24,30,34 \\
38\end{array}$ & 0,8 \\
\hline $\begin{array}{l}\text { Normas relativas à } \\
\text { demissão de colaboradores }\end{array}$ & $\begin{array}{l}\text { Presença ou ausência de normas } \\
\text { organizacionais definidas para demissão de } \\
\text { colaboradores, permitindo, ou não, ao } \\
\text { empregado prever sua permanência na } \\
\text { organização. }\end{array}$ & 6 & $\begin{array}{c}1,5,20,12^{*} \\
28^{*}, 41\end{array}$ & 0,79 & 6 & $\begin{array}{c}1,5,12^{*}, 20 \\
28^{*}, 41\end{array}$ & 0,79 \\
\hline $\begin{array}{l}\text { Reconhecimento financeiro } \\
\text { organizacional }\end{array}$ & $\begin{array}{l}\text { Os esforços dos colaboradores são } \\
\text { reconhecidos e valorizados de forma } \\
\text { financeira, principalmente, por meio de } \\
\text { salário. A concessão de aumento salarial é } \\
\text { percebida como uma das manifestações de } \\
\text { reconhecimento por parte da organização. } \\
\text { Esse reconhecimento financeiro beneficia } \\
\text { ambas as partes. }\end{array}$ & 5 & $\begin{array}{c}15,31,40 \\
44,47\end{array}$ & 0,83 & 5 & $\begin{array}{c}15,31,40 \\
44,47\end{array}$ & 0,83 \\
\hline Padrões éticos & $\begin{array}{l}\text { Refere-se a princípios éticos como } \\
\text { honestidade, igualdade, transparência da } \\
\text { organização ao divulgar informações, } \\
\text { responsabilidade, manutenção de } \\
\text { compromissos e respeito. Tais princípios } \\
\text { orientam a relação da organização com seus } \\
\text { clientes e colaboradores ao procurar não } \\
\text { prejudicar aqueles com os quais se relaciona. }\end{array}$ & 17 & \begin{tabular}{|c|}
$3,6,7,9,10$ \\
$13,14,16$ \\
$23,25,27$ \\
$35,36,39$ \\
$42,43,46$
\end{tabular} & 0,93 & 7 & \begin{tabular}{|c|}
$3,9,10,35$ \\
$36,43,46$
\end{tabular} & 0,88 \\
\hline
\end{tabular}

Fonte: Adaptado de OLIVEIRA, A. F., \& TAMAYO, A. Confiança do empregado na organização, 2008

As questões são apresentadas a seguir. As questões que pertencem à versão reduzida estão acompanhadas do símbolo ${ }^{\circledR}$. 


\section{Questionário da Escala de Confiança do Empregado na Organização - ECEO}

1) Na sua organização, um colaborador pode ser demitido sem receber explicações convincentes.

2) Acredito que a sua organização terá um futuro prospero.

3) A sua organização é ética.

4) A sua organização cumpre suas obrigações financeiras com os colaboradores.

5) A sua organização considera apenas seus próprios interesses.

6) A sua organização cumpre o que promete aos seus colaboradores.

7) O relacionamento da sua organização com seus colaboradores é baseado na honestidade.

8) Acredito na estabilidade financeira da sua organização.

9) $\mathrm{O}$ colaborador pode acreditar nas informações que a sua organização divulga.

10) Para a sua organização, o cliente tem o direito de ser informado sobre os assuntos que the dizem respeito.

11) A sua organização oferece condições reais para que o colaborador se desenvolva.

12) A demissão de colaboradores segue um procedimento conhecido por todos. $(*)$

13) A sua organização evita prejudicar pessoas com as quais se relaciona.

14) A conduta dos colaboradores é orientada pela ética da sua organização.

15) O salário pago pela sua organização corresponde aos esforços do colaborador.

16) $\mathrm{O}$ trabalho na sua organização tem normas claras.

17) As pessoas acreditam que a sua organização continuará existindo nos próximos anos.

18) A sua organização consegue sobreviver às interferências do governo.

19) A sua organização segue normas para promover seus colaboradores.

20) Os dirigentes da sua organização demitem os colaboradores baseando-se em julgamentos pessoais.

21) A sua organização oferece oportunidades de crescimento profissional ao colaborador.

22) A comunicação entre a sua organização e os colaboradores é clara.

23) Na sua organização os colaboradores são respeitados, independente do cargo ocupado.

24) A sua organização ocupa uma posição segura na sua área de atuação.

25) A sua organização possui um código de ética que orienta suas ações.

26) Os salários dos colaboradores são pagos na data prevista pela sua organização.

27) A honestidade é uma característica da sua organização.

28) As normas para demissão de colaboradores são claras. (*)

29) A sua organização é forte no seu ramo de atuação.

30) A sua organização está preparada para sobreviver às crises econômicas.

31) Os contratos estabelecidos pela sua organização são vantajosos para todos.

32) As normas da sua organização são mantidas ao longo do tempo.

33) A sua organização incentiva o crescimento profissional de seus colaboradores.

34) A solidez econômica da sua organização dá segurança aos colaboradores.

35) Os clientes da sua organização sabem que podem acreditar na solidez da sua organização.

36) A sua organização é conhecida por trabalhar de maneira responsável.

37) A sua organização transmite informações claras a seus colaboradores.

38) A sua organização é conhecida pelo seu poder econômico.

39) As normas da sua organização são aplicadas a todos os seus membros.

40) A sua organização valoriza o trabalho do colaborador financeiramente.

41) Aqui os colaboradores são demitidos a qualquer momento, independente das normas da organização.

42) A sua organização tem boas intenções ao se relacionar com outras organizações.

43) Ser honesta com os clientes é princípio ético da sua organização.

44) Aumentar salário é uma forma de reconhecimento da sua organização.

45) O plano de carreira da sua organização permite o crescimento profissional do colaborador.

46) O cliente é respeitado na sua organização.

47) O trabalho do colaborador é reconhecido na sua organização por meio do salário. 


\title{
3.3.
}

\section{Universo e Amostra}

O universo desta pesquisa pertence ao ambiente organizacional de duas empresas de transporte de passageiros, com sede na Baixada Fluminense e atuação na região metropolitana do Rio de Janeiro.

Do total de 2.668 motoristas da empresa A, 385 representam a amostra, representando $14,4 \%$ da população total. Já a empresa B, possui 632 motoristas, dos quais 222 responderam ao questionários, representando $35 \%$ da população. A escolha e coleta da amostra ocorreram de maneira não probabilística, não intencional, obedecendo ao critério da conveniência, quando o pesquisador seleciona membros da população mais acessíveis.

De acordo com Mattar (2001), a amostragem não probabilística é aquela em que a seleção dos elementos da população para compor a amostra depende, ao menos em parte, do julgamento do pesquisador ou do entrevistador no campo.

\begin{abstract}
O resultado de um processo de amostragem probabilístico a priori pode resultar em um estudo não probabilístico devido a erros que os entrevistadores podem cometer quando não seguem corretamente as instruções. Outro motivo pode ser que a obtenção de uma amostra de dados que reflitam precisamente a população não seja o proposito principal da pesquisa. Se não houver intenção de generalizar os dados obtidos na amostra para a população, então não haverá preocupações quanto à amostra ser mais ou menos representativa da população. (MATTAR, 1996, P.157)
\end{abstract}

Ainda de acordo com Mattar (1996), embora a amostragem probabilística seja uma técnica reconhecidamente superior, outras razões para o uso de amostragem não probabilística se referem às limitações de tempo, recursos financeiros, materiais e mão-de-obra necessários para a realização de uma pesquisa com amostragem probabilística.

\section{4.}

\section{Procedimentos e Instrumentos de Coleta de Dados}

A coleta de dados utilizou tanto dados primários, quanto secundários. A pesquisa documental foi realizada em documentos, contratos, estatutos, regulamentos, circulares, manuais, relatórios, atas de reunião e outros documentos disponibilizados pelas empresas $\mathrm{A}$ e $\mathrm{B}$, foco de análise. Com base nestas informações foi elaborado o capítulo 4 a seguir, que contextualiza as duas organizações e descreve os seus índices de rotatividade e absenteísmo. 
Na pesquisa de campo, os dados foram coletados através da aplicação de questionários. Para Marconi e Lakatos (2005), o questionário é um instrumento de coleta de dados, constituído por uma série ordenada de perguntas, que devem ser respondidas por escrito sem a presença do entrevistador. Tal procedimento foi escolhido por abranger muitas pessoas simultaneamente, colher respostas rápidas precisas, propiciar maior liberdade nas respostas por conta do anonimato, minimizar os riscos de distorção, pela não influência do pesquisador e por favorecer uniformidade na avaliação, pela impessoalidade do instrumento.

Tanto na Empresa $A$, quanto na Empresa $B$ os questionários foram aplicados durante reuniões semestrais, cujo objetivo é informar aos motoristas os resultados da empresa. Tal ocasião foi escolhida por ser o único momento em que é possível reunir uma grande quantidade de colaboradores, tanto do primeiro quanto do segundo turno, em função da amplitude dos horários de trabalho.

O preenchimento do questionário se deu após uma breve explicação sobre a proposta da pesquisa e da forma correta de preenchimento do documento, tomando como referência a experiência dos respondentes em relação à organização em que trabalha, e não apenas em sua área de atuação. As informações coletadas foram tabuladas e tratadas estatisticamente através de softwares específicos.

\section{5.}

\section{Análise e Interpretação dos Dados}

Em primeiro lugar, os questionários foram numerados e digitados no banco de dados do programa estatístico SPSS (Statistical Package for Social Sciences), versão 17.0. Foram, então, retirados do banco aqueles respondentes que não responderam integralmente o questionário, deixando alguma resposta em branco.

\section{6.}

\section{Limitações do Método}

No presente estudo, existem limitações no instrumento de pesquisa aplicado, na escolha das organizações estudadas, na amostra apresentada, na escolha dos instrumentos e na forma de aplicação da pesquisa.

Por se tratar de um estudo de caráter exploratório-descritivo, com abordagem qualitativa, realizado através de pesquisa de campo, Babbie (1999) e 
Bryman (1989) consideram como algumas desvantagens a impossibilidade de realizar observações ou coletar documentos adicionais, falta de certeza de quem está respondendo ao questionário e a obrigatoriedade de clareza das questões e no formato do questionário facilitando a compreensão do respondente.

Existem limitações quanto à escolha dos participantes da pesquisa, uma vez que a delimitação pode levar um viés de locus, resultando do fato de todos os respondentes estarem inseridos em apenas duas organizações. Porém, uma vez que o objetivo do presente estudo é analisar a influência da confiança organizacional no âmbito de duas empresas, é até desejável que o grupo de participantes seja o mais homogêneo possível.

O método fica limitado pela seleção dos pesquisados, tendo em vista a impossibilidade de serem pesquisados todos os funcionários da empresa. Dessa forma, não há como realizar generalizações a respeito do resultado, pois esta representa parte do público-alvo e não a sua totalidade. Além disso, não houve a possibilidade da análise das representações simbólicas e percepções de todos os segmentos da organização, apenas da amostra analisada.

O estudo comparativo de casos representa uma pequena amostra da realidade. Portanto, as análises serão gerais e podem não representar a realidade da população verificada. Segundo Yin (2001), esse processo é classificado de generalização analítica.

Deve-se considerar também o fato do pesquisador ser colaborador de uma das empresas pesquisadas, o que pode ocasionar um viés na análise dos resultados. 


\section{4 \\ Contextualização das Empresas}

\section{1.}

O Transporte Público no Brasil

Há um consenso no que diz respeito à extrema importância do transporte público na vida de um país. Contudo, não há uma clara noção do que representa, em termos quantitativos, a presença e influência dos transportes públicos e seus profissionais na vida da sociedade.

Segundo dados da Associação Nacional de Empresas de Transportes urbanos (NTU), a frota de ônibus brasileira em 2012 atingia mais de 107 mil veículos. Somente na cidade do Rio de Janeiro cerca de 100 milhões de passageiros são transportados por mês. Esses números mostram a urgência do planejamento do crescimento das cidades, bem como a estruturação e organização do transporte público para atender a este número crescente de pessoas deslocando-se nas áreas urbanas.

Em relatório de consultoria prestada ao Denatran pela FGV (1999), o trânsito, definido como movimentação e imobilização de veículos, pessoas e animais nas vias terrestres, é visto como um sistema de três elementos essenciais: via, veículo e homem.

Há a exigência de que as vias e os veículos estejam em condições perfeitas, ou seja, vias sem buracos e bem sinalizadas e veículos com todas as luzes funcionando, freios, pneus, etc. Todavia, o motorista, componente mais importante para a organização e segurança do transito, não tem suas condições verificadas. Esta falta de atenção com as necessidades do homem é ainda mais grave no caso dos motoristas profissionais que dependem de esforços do Estado e de suas empresas para que boas condições de trabalho sejam atingidas.

Em documentos de órgãos ligados ao transporte público como ANTP (2000) e NTU (1998), o motorista é sempre tratado tão tecnicamente quanto as vias e os veículos o são. Há a preocupação com a educação que trata, em termos gerais, de como o motorista deve proceder no trânsito. São citadas as causas mais comuns de acidentes como uso do álcool, doença crônica, doença física, excitação emocional, etc. No entanto, não se vai ás raízes desses 
problemas. No caso especifico do motorista de ônibus, não há maiores questionamentos sobre condições de trabalho, confiança e satisfação no trabalho. Consequentemente, para que o comportamento adequado no transito seja alcançado recorre-se, principalmente, à vigilância, e às punições, em substituição à educação e à oferta de condições adequadas de trabalho.

O tamanho da indústria e a importância do transporte público e seus profissionais, em especial dos ônibus, podem ser visualizadas a seguir, na Tabela 2, onde são apresentadas informações sobre a quantidade de passageiros transportados por mês somente na cidade do Rio de Janeiro, bem como o tamanho da frota de ônibus no município.

Tabela 2: Dados Mensais Município do Rio de Janeiro - 2014

\begin{tabular}{cccccc} 
№ de Linhas & Frota & $\begin{array}{c}\text { Passageiros } \\
\text { Pagantes }\end{array}$ & Gratuidades & Idade Frota & Funcionários \\
\hline 724 & 9.005 & 91.960 .138 & 17.418 .131 & 4,25 & 41.375 \\
\hline
\end{tabular}

Fonte: Databank Fetranspor / Rioônibus

Segundo documento da Associação Nacional de Transporte Público ANTP, a maioria das cidades brasileiras foi adaptada para o uso do automóvel, privilegiando uma classe que tinha condições financeiras de optar pelo uso do carro ou transporte individual. Com isso, criou-se a cultura do automóvel, na qual este representa a única opção eficiente de transporte. Como consequência, gerou-se um direcionamento de investimentos para melhorias de condições de vias, visando ao automóvel e, ainda, uma crescente desvalorização do transporte público e seus profissionais.

Em publicação da Associação Nacional de Empresas de Transporte Urbano - NTU, fala-se dessa tendência de valorização do transporte individual, acrescentando que há uma grave distorção do governo no que diz respeito aos investimentos, em geral, beneficiam os veículos particulares, enquanto os investimentos em transporte público são totalmente arcados pelos seus usuários. De acordo com a NTU, esta lógica totalmente incoerente inviabilizou inúmeros projetos de melhoria de transporte urbano.

A NTU salienta, ainda, a necessidade de campanhas de revalorização, qualificação e priorização do transporte coletivo urbano, deixando de ser um "mal necessário" para se tornar uma boa opção. 
Os principais problemas decorrentes dessa cultura do automóvel, aliados aos problemas já existentes nas médias e grandes cidades brasileiras, são salientados por associações como a NTU (2010) e a ANTP (2011), a saber:

a) O crescimento desordenado das cidades gera prejuízos para toda a sociedade, principalmente para a população de baixa renda.

b) A queda da qualidade do transporte público que gera uma crescente degradação da qualidade de vida urbana refletindo-se na dificuldade de acesso às áreas urbanas, no aumento de congestionamento e aumento da poluição do ar e, ainda, no crescente número de veículos em áreas residenciais e de uso coletivo.

c) O congestionamento crônico que, por sua vez, dá inicio a diversos prejuízos para a sociedade como um todo, a saber:

1. Eleva o tempo de viagem e reduz a produtividade de atividades urbanas. Estima-se que os prejuízos resultantes do congestionamento severo cheguem a $\mathrm{R} \$ 25$ bilhões por ano somente nas grandes cidades.

2. O desempenho dos ônibus também é extremamente atingido pelos congestionamentos severos. A velocidade dos ônibus é reduzida e fixada muito abaixo dos desejáveis $25 \mathrm{~km} / \mathrm{h}$.

3. O tempo gasto pelos passageiros diariamente nos transportes coletivos eleva-se muito com os congestionamentos, chegando até a mais de três horas por dia. Além disso, os congestionamentos geram ainda um aumento significativo dos custos de operação dos ônibus que atingem até $16 \%$ no caso de São Paulo (IPEA/ANTP, 1998).

Todos esses problemas, acrescidos do aumento do transporte clandestino, diminuem a atratividade do transporte público, fazendo com que, principalmente, a classe média opte pelo transporte individual, agravando ainda mais a situação do transporte urbano no Brasil.

Essa desorganização do transporte urbano tem gerado grandes perdas para o país em termos de poluição, gasto de combustível e congestionamento. Além dessas perdas, a ANTP cita ainda outros custos para a sociedade de um transporte urbano mal estruturado como, por exemplo, os investimentos que as cidades deixam de receber de empresas, uma vez que elas não oferecem condições e qualidade de vida aceitáveis para tal.

Algumas sugestões para a melhoria do transporte urbano são dadas por associações como a ANTP (2011) e a NTU (2010). Em primeiro lugar, é sugerido 
que os três níveis de governo (municipal, estadual e federal) estejam igualmente envolvidos na priorização do transporte público. Segundo, é preciso promover a participação do setor privado na análise, sugestão e aplicação de soluções para a questão do transporte. Há também a necessidade de conscientização da população da importância do uso do transporte coletivo em detrimento do individual.

\section{2.}

\section{O Motorista de ônibus}

As pessoas utilizam as vias públicas para passeio ou para se deslocarem deliberadamente (levar os filhos à escola, ir e vir de seus locais de trabalho, etc.), além das que as utilizam como meio de exercer o seu trabalho. Entre os profissionais que atuam no trânsito, destacam-se os motoristas de transporte coletivo urbano. O trabalho destes profissionais consiste em fazer contínuos deslocamentos levando e trazendo pessoas aos destinos predeterminados. Possui um "macro" local de trabalho que é o trânsito, e um "micro", que é o ônibus. Por esta peculiar característica nenhum outro profissional sofre tanto as pressões do ambiente viário quanto os motoristas (BATTISTON et al., 2006).

Hoffmann (2000) afirma que estas pressões têm origens externas e internas. Por pressões externas destacam-se as exigências do trânsito (ambiente), o respeito ao sistema convencional de normas (código), os limites de seu trabalho como, por exemplo, nível do tráfego, semáforos, congestionamentos, acidentes, além de condições adversas como o clima e o estado de conservação da pista. Por pressões internas destacam-se as condições ergonômicas do veículo: posição do motor, precariedade mecânica, além do ruído e das vibrações.

O trabalho dos motoristas profissionais no Brasil é caracterizado por ser rotineiro e por apresentar condições de trabalho inadequadas, ou seja, jornadas excessivas, noites mal dormidas, hábitos alimentares inadequados e violência urbana (SEST, 2001). Um estudo realizado em 2000, pela Fundação SEADE, com 1762 motoristas de ônibus da região metropolitana de São Paulo, sobre as condições de saúde e segurança dos motoristas, revelou péssimas condições de trabalho, como: longos percursos, pausas para refeição muito curtas, precárias condições dos veículos, motoristas com mais de 10 horas diárias (22\%).

Cavalcanti (1996) relata que os motoristas de ônibus são expostos diariamente a uma variedade de estressores ambientais, tais como: ruídos do motor, da porta e da buzina; iluminação inadequada; altas temperaturas; 
exposição a poluentes atmosféricos, principalmente provenientes de escapamentos de veículos (monóxido de carbono) e poeira (pó do asfalto); e o relacionamento com os passageiros e chefias, que muitas vezes passa a ser conflituoso, podendo levar a desequilíbrios psicoemocionais.

Os motoristas de ônibus estão submetidos às normas da empresa para a qual trabalham de forma peculiar, pois permanecem a maior parte da jornada de trabalho fora dos limites convencionais de uma empresa. Esse aspecto geralmente implica em atribuição de normas rígidas de fiscalização no que diz respeito ao cumprimento de horários (independente das pressões externas e internas), cuidados com o veículo (dado que são responsáveis por qualquer dano ao mesmo), diversidade dos comportamentos dos passageiros (pressão interna), além da responsabilidade que têm sobre a vida das pessoas que conduzem durante horas diárias (BATTISTON et al., 2006).

Como o transporte coletivo adquire uma importância social e econômica cada vez maior, transportando milhões de passageiros diariamente, o comportamento dos seus operadores é de significativa importância para o desempenho de atividades consideradas essenciais à população. Falhas no trabalho podem colocar em risco não só a vida do motorista, como também a vida de muitas pessoas (RAMOS, 1991).

\section{3. \\ As Empresas Estudadas}

De acordo com Lebleci e Shah (2004), o relato de histórias empresariais tendem a engrandecer os feitos do passado, a narrar de forma épica as dificuldades dos anos iniciais, a romantizar a atuação dos líderes em períodoschave, enfim, a contar a história da empresa como se fosse um relato oficial e único de fatos - e não de uma versão, entre as várias possíveis. As narrativas podem ser utilizadas pelas empresas para fortalecer os vínculos com seus funcionários e fornecedores - por meio de uma "história de vida corporativa" que expressa solidez, segurança financeira e princípios éticos (COSTA et al., 2009).

Já Costa e Saraiva (2011) entendem que a referência ao passado, bem como a apropriação de interpretações acerca deste passado, torna possível a coesão e a definição dos papéis dos mais diferentes grupos e organizações que formam uma empresa. Ainda de acordo com os autores, a memória organizacional é recorrentemente construída, reconstruída e disseminada em suas estruturas. Isso significa que se assiste a um significativo embate simbólico nas organizações no que diz respeito ao passado. 
Nesse sentido, buscou-se fazer uma breve reconstituição do passado das duas empresas analisadas, com o objetivo de traçar um paralelo entre a história de cada empresa e o momento atual vivenciado por ambas as organizações. Para tal, foram feitas entrevistas com funcionários e fornecedores, além de ampla consulta ao acervo das duas empresas.

\subsection{1.}

\section{Empresa A}

O desenvolvimento da cidade de São João de Meriti, na Baixada Fluminense, se confunde com a fundação da empresa A, no ano de 1957. O início da operação foi fundamental para alavancar o crescimento do município, uma vez que a população estava concentrada ao longo da Estrada de Ferro, e as primeiras linhas de ônibus foram importantes para garantir os deslocamentos dos moradores no entorno da ferrovia. Inicialmente, a empresa conseguiu autorização do Departamento de Estradas de Rodagem para operar a linha que ligava São João de Meriti a Duque de Caxias, a primeira das mais de 50 linhas em operação atualmente. Extremamente tradicional na região, a companhia se estruturou durante a década de 60 , mas teve seu crescimento acentuado a partir de 1975 quando os atuais acionistas adquiriram a empresa.

\subsubsection{1. Liderança}

"Um homem inteligente, obstinado, empreendedor, apaixonado por transporte e que valorizava o ser humano acima de tudo", assim foi definido o novo proprietário da empresa $A$ por um de seus funcionários. Dentre os

princípios que permeavam atitudes e decisões do empresário, destaca-se a valorização do funcionário, comportamento ainda raro numa época em que as teorias contemporâneas de administração e liderança não faziam parte do dia-adia dos gestores. O empresário costumava afirmar que "para uma empresa ter sucesso, o fator mais importante são as pessoas que nela trabalham. Elas precisam ter bem-estar e tranquilidade para desempenhar bem o seu papel".

Com essa visão, o empresário programou mudanças voltadas para o bemestar dos colaboradores e para uma participação maior destes, visando ao crescimento da empresa e ao desenvolvimento individual de cada colaborador. O pioneirismo da gestão da Empresa A ficou mais evidente durante os anos 1980, período marcado pela evolução em questões como treinamento, capacitação e ambiente de trabalho, mas principalmente pela integração dos 
colaboradores. Em 1982, foi criado um jornal para os colaboradores, inaugurado o campo de futebol e implantados o departamento de Recursos Humanos e departamento Médico, bem como benefícios que melhoravam a qualidade de vida dos colaboradores.

\subsubsection{2.}

\section{Gestão da Qualidade}

A década de 90 marca a perda do líder, mas também o compromisso da segunda geração com a manutenção dos valores já disseminados na empresa. Durante esse período de transição, é importante destacar o desenvolvimento do modelo de Gestão da Qualidade, através da criação de times de melhorias, cujo objetivo era incentivar a participação mais ativa dos colaboradores na busca por melhores resultados em áreas específicas, como redução de acidentes de transito e redução do consumo de combustível, entre outras.

A partir de 1998 a Empresa A iniciou seu Planejamento Estratégico Corporativo, que resultou não apenas na definição de metas em longo prazo, mas na criação do programa de metas compartilhadas e no realinhamento da missão e visão de futuro, bem como na definição da filosofia empresarial que orientaria a trajetória da empresa nos próximos anos. Nesse período, a organização inova mais uma vez ao iniciar a divulgação do seu Balanço Social do ano de 1997.

Nas décadas de 1990 e 2000, a Empresa A se destacou em diversos processos de premiação, que avaliavam a evolução do seu Sistema de Gestão. A partir de 2005, a empresa definiu como estratégia estar entre as melhores empresas para se trabalhar e para isso continua investindo maciçamente em ações que possam proporcionar aos colaboradores o melhor ambiente de trabalho e melhores oportunidades de crescimento profissional. Em 2011, a organização manteve sua visão de futuro de estar entre as melhores empresas até 2016 e definiu outro importante foco, que é a certificação do seu Sistema Integrado de Gestão pelas normas ISO 9001 (para o Sistema da Qualidade), ISO 14001 (Para o Meio Ambiente) e OHSAS 18001 (para Saúde e Segurança).

É importante destacar que a Empresa A sempre foi pioneira na gestão e na valorização dos seus funcionários. Os valores trazidos pelo empresário que adquiriu a empresa em 1975 permanecem vivos e fazem parte do dia-a-dia dos mais de 3.000 colaboradores. A empresa é considerada um dos principais benchmarking do setor, não apenas pela sua estrutura grandiosa, mas principalmente pela sua gestão inovadora. 


\subsection{2.}

\section{Empresa B}

Fundada em 1964, no município de Seropédica, a empresa B obteve autorização junto ao Departamento de Estradas de Rodagem para fazer a ligação entre os municípios de Nilópolis e Seropédica. Posteriormente, em 1975, a empresa passou a ligar a baixada fluminense ao bairro de Campo Grande, localizado na zona oeste do Rio de Janeiro, o que motivou a mudança da sua sede para o bairro de Cabuçu, no município de Nova Iguaçu.

Esse período, marcado por grandes dificuldades financeiras, obrigava os antigos acionistas a administrar a empresa de maneira austera, sem grandes investimentos em melhoria de frota, ou na busca por melhores condições de trabalho para os colaboradores. Era comum ouvir a máxima "vender o almoço para pagar o jantar", e o objetivo era sobreviver ao transporte pirata e às péssimas condições das vias onde a empresa operava suas linhas.

O ápice desse tempo difícil ocorreu em 1985, quando o então governador do Rio de Janeiro, Leonel Brizola, encampou 16 empresas de ônibus que atuavam na região metropolitana do Rio de Janeiro, incluindo a empresa B. Sua administração foi entregue a pessoas indicadas pelo governo estadual e essa situação permaneceu por três anos. Em 1988, a administração da empresa foi devolvida ao antigo acionista, contudo, sua frota foi sucateada em função da má manutenção sofrida durante a encampação.

\subsubsection{1. Mudanças na Gestão}

Todas as decisões eram tomadas pelo antigo dono, desde assuntos estratégicos, como renovação de frota ou negociações com fornecedores, o momento correto de fazer a manutenção dos veículos, até assuntos mais operacionais, como o atendimento a funcionários que faltavam ao trabalho. Essa centralização de poder e a ausência de planejamento acabavam desestimulando os colaboradores, que também eram obrigados a conviver com constantes atrasos de salários.

O ano de 2000 marca a mudança no controle acionário da empresa B, quando o antigo empresário deixa suas funções à frente da organização. Esse momento é importante pela profunda alteração no estilo de gestão da empresa e, sobretudo, na relação com os funcionários. Inicia-se um período de intensa valorização do colaborador, além de investimentos mais constantes em 
renovação de frota, atualização dos sistemas de controle e, principalmente, na capacitação dos empregados.

Como exemplo dessa mudança de gestão, a empresa B passa a adotar o programa de metas compartilhadas, que originou a formação de times de trabalho, com o objetivo de buscar uma participação mais ativa dos colaboradores. A organização também passou a investir na formação dos colaboradores e, com o desenvolvimento dos processos internos, passou a dar oportunidade de crescimento profissional a um número cada vez maior de colaboradores. Além disso, a empresa passou a contar com departamento médico, refeição no local de trabalho e o principal, na visão de muitos funcionários, o fim de atrasos no pagamento de salários.

Apesar das dificuldades enfrentadas pela empresa B desde a sua fundação, especialmente em função do desequilíbrio financeiro, observa-se que houve um amadurecimento da organização na última década. O investimento em treinamento e a capacitação dos profissionais, bem como um cuidado maior com as condições de trabalho e bem-estar dos funcionários, levaram ao aumento da satisfação dos colaboradores e, consequentemente, a resultados melhores para a companhia.

\section{4.} Perfil da Rotatividade das Empresas Analisadas

Os setores de gestão de pessoas tanto da empresa A quanto da empresa $B$ realizaram um levantamento buscando informações precisas sobre as taxas de rotatividade verificadas nos últimos quatro anos. Nesse estudo, a rotatividade é analisada individualmente para a função de motorista de ônibus, ou seja, são desconsiderados os dados de admissão e demissão referentes a qualquer outra função, as quais podem ser observadas na Tabela 3. 
Tabela 3: Taxas de Rotatividade das Empresas

\begin{tabular}{c|c|c}
\hline Ano & Empresa A & Empresa B \\
\hline 2012 & $15 \%$ & $23 \%$ \\
2013 & $13 \%$ & $24 \%$ \\
2014 & $14 \%$ & $22 \%$ \\
2015 & $7 \%$ & $16 \%$ \\
\hline
\end{tabular}

Fonte: Desenvolvido pelo autor com base em documentos fornecidos pelas empresas estudadas

É possível observar que durante o período analisado, a rotatividade da empresa $B$ sempre se mantem em níveis mais elevados do que na empresa $A$.

Apesar de estarem localizadas muito próximas uma da outra, o mercado de trabalho das cidades de São João de Meriti e Nova Iguaçu apresentam características bastante diferenciadas, especialmente em relação ao setor de transportes. A diferença de rotatividade pode ser explicada pelo fato de Nova Iguaçu possuir diversas empresas de transporte de passageiros, além de apresentar uma quantidade maior de opções para motoristas profissionais, especialmente no mercado de caminhões. Já São João de Meriti, não possui outra empresa de ônibus que não a empresa $A$, além de ser um município cuja economia é mais fraca e o mercado de trabalho não oferece tantas opções para motoristas profissionais.

A situação acima descrita ilustra o comportamento pró-cíclico da rotatividade, aumentando o número de desligamentos voluntários à medida que o mercado de trabalho aquece, visto que os trabalhadores buscam melhores oportunidades de emprego. Contudo, a partir de 2015 observa-se uma reversão dessa situação, ou seja, em períodos recessivos, tanto as contratações quanto os desligamentos voluntários reduzem ao passo que as demissões por iniciativa do empregador aumentam (MEDEIROS et al., 2010).

A queda significativa da rotatividade de ambas as empresas em 2015, ano marcado pela incerteza economia e desaquecimento do mercado de trabalho, vai ao encontro do modelo proposto por Price (1977). O autor destaca que ao analisar a relação entre satisfação, oportunidade e rotatividade, percebe-se que se não há oportunidade no mercado de trabalho, o trabalhador insatisfeito permanece na empresa, reduzindo, portanto, a rotatividade. 
Esses dados também corroboram o modelo de Steers e Mowday (1981), que é formado por três grandes eixos, sendo intenção de sair e possibilidade de recolocação no mercado de trabalho a principal desencadeadora da rotatividade voluntária.

Finalmente, essa situação também é prevista no estudo de Spector (2002), onde a taxa de desemprego é considerada não apenas uma causa, mas também um moderador de rotatividade, ou seja, quando existe a incerteza quanto a disponibilidade de vagas de emprego no mercado, o trabalhador tende a não se arriscar em pedir ou provocar a sua demissão.

Diante do exposto, vale lembrar que a redução da rotatividade ocasionada pela conjuntura econômica comprova os modelos propostos pelos pesquisadores que adotam o campo da Teoria Econômica como base de estudos. Contudo, esses modelos são criticados por considerar apenas variáveis monetárias para a explicação do fenômeno da rotatividade (RIBEIRO, 2001; HAUSKNECHT \& HOLWERDA, 2013).

\section{5.}

\section{O Absenteísmo das Empresas Analisadas}

Conforme levantamento realizado pelas áreas de Gestão de Pessoas das duas empresas, a questão do absenteísmo foi analisada a partir do isolamento dos dados referentes aos motoristas profissionais, não sendo levada em conta qualquer outra função, conforme a Tabela 4.

Tabela 4: Taxas de Absenteísmo das Empresas

\begin{tabular}{c|c|c}
\hline Ano & Empresa A & Empresa B \\
\hline 2012 & 2,01 & 2,91 \\
2013 & 1,89 & 2,81 \\
2014 & 2,07 & 2,37 \\
2015 & 1,89 & 2,02 \\
\hline
\end{tabular}

Fonte: Desenvolvido pelo autor com base em documentos fornecidos pelas empresas estudadas 
É possível observar que a durante o período analisado os níveis de absenteísmo da empresa $B$ se mantiveram superiores aos níveis de absenteísmo apresentados pela empresa $A$.

Assim como na análise da rotatividade, observa-se uma tendência de redução do absenteísmo no ano de 2015, porém menos acentuada do que no caso descrito acima. São poucos os autores que correlacionam a conjuntura econômica ao absenteísmo. Nesse sentido, vale destacar o estudo empírico de Harrison e Martocchio (1998), que analisa a influência de variáveis macroeconômicas nos índices de absenteísmo. O autor aponta a existência de uma relação inversa entre absenteísmo e desemprego, ou seja, quanto mais aquecido estiver o mercado de trabalho, maior é a tendência de o empregado faltar voluntariamente ao trabalho.

Apesar de o levantamento demonstrar números favoráveis a empresa $A$ em todos os anos, não foi possível pressupor uma relação direta entre absenteísmo e confiança, a partir das cinco dimensões propostas pelo modelo de Oliveira e Tamayo (2008), quais sejam: Promoção do crescimento do empregado, Reconhecimento financeiro do empregado, Solidez organizacional, Padrões éticos e Normas relativas a demissão dos empregados com o constructo absenteísmo.

Segundo a literatura pesquisada, diversos autores apresentaram estudos empíricos que relacionam 0 absenteísmo voluntário ao comportamento organizacional (BRIEF, 2002; HARRISON \& MARTOCCHIO, 1998; DALTON \& MESCH, 1991; MCDONALD \& SHAVER, 1981; STEEL, 2003, JOHNS, 2003, JOHNSON \& O'LEARY, 2003). Os estudos concentram-se em correlacionar 0 absenteísmo com fatores micro-organizacionais (como satisfação, sexo, gênero, idade, educação). Contudo, não há um arcabouço literário quanto a relação entre confiança organizacional e absenteísmo.

Uma justificativa para esse fenômeno diz respeito a grande quantidade de fatores que podem servir de gatilho para a abstenção do empregado, entre eles destacam-se os motivos de curto prazo, relacionados a problemas de tomada de decisão, como impedimentos, estresse físico e mental e pressão social; os motivos de médio prazo, relacionados a atitudes e contexto social, como adoção de horário flexível, comprometimento, envolvimento e satisfação; e, finalmente, os motivos de longo prazo, relacionados a características demográficas e problemas crônicos de saúde, como gênero, idade, hábito de fumar, alcoolismo, consumo de drogas e exercícios físicos (HARRISON \& MARTOCCHIO, 1998). 
Portanto, não é possível verificar a influência direta da confiança organizacional nos níveis de absenteísmo das empresas de transporte de passageiros. Deste modo, pressupõe-se que não é verdadeira a premissa " $O$ constructo confiança organizacional impacta positivamente 0 índice de absenteísmo das empresas de transporte de passageiros", proposta nesse estudo.

Como não é possível pressupor a influência direta da confiança organizacional nos níveis de absenteísmo das empresas, o próximo capítulo discutirá somente os resultados referentes à relação entre confiança organizacional e rotatividade. 


\section{5}

\section{Análise dos Resultados}

Neste capítulo são apresentadas as propriedades estatísticas, seguidas pela discussão dos resultados obtidos para cada uma das cinco dimensões e sua relação com a rotatividade das empresas analisadas.

\section{1 .}

\section{Análise e Discussão}

De acordo com os escores obtidos pelos respondentes quando do preenchimento da Escala de Confiança do Empregado na Organização - ECEO (OLIVEIRA \& TAMAYO, 2008), foi possível observar diferenças latentes em relação ao nível de concordância dos respondentes de cada organização.

Em relação às respostas da empresa $A$, observadas na Tabela 5 , percebese que $47 \%$ concordam com a Solidez organizacional. Já Promoção do crescimento do empregado, reconhecimento financeiro organizacional e padrões éticos tiveram alto percentual de respondentes indiferentes, com 43\%, 44\% e $42 \%$, respectivamente. Finalmente, a dimensão Normas relativas à demissão dos empregados apresentou $49 \%$ de discordantes.

Tabela 5: Confiança na Organização - Frequência (Empresa A)

\begin{tabular}{|c|c|c|c|c|c|c|c|}
\cline { 4 - 7 } \multicolumn{2}{l|}{} & $\begin{array}{c}\text { Promoção do } \\
\text { crescimento do } \\
\text { empregado }\end{array}$ & $\begin{array}{c}\text { Reconhecimento } \\
\text { financeiro } \\
\text { organizacional }\end{array}$ & $\begin{array}{c}\text { Solidez } \\
\text { organizacional }\end{array}$ & Padrões éticos & $\begin{array}{c}\text { Normas relativas } \\
\text { à demissão de } \\
\text { empregados }\end{array}$ \\
\hline Discordância & $\begin{array}{c}\text { Escore } \\
\text { Médio } \\
\text { até } 2,9\end{array}$ & $\mathrm{~N}$ & 56 & $15 \%$ & 42 & 95 & 189 \\
\hline Indiferença & $\begin{array}{c}\text { Escore } \\
\text { Médio } \\
\text { entre 3 } \\
\text { e 3,9 }\end{array}$ & $\mathrm{N}$ & 165 & $40 \%$ & $11 \%$ & $25 \%$ & $49 \%$ \\
\hline Concordância & $\begin{array}{c}\text { Escore } \\
\text { Médio } \\
\text { entre 4 } \\
\text { e 5 }\end{array}$ & $\mathrm{N}$ & $13 \%$ & $44 \%$ & $42 \%$ & $42 \%$ & 113 \\
\hline
\end{tabular}

Fonte: Dados da pesquisa 
Já o padrão de respostas da empresa B (Tabela 6) apresentou comportamento similar para a dimensão Normas relativas à demissão de empregados, com $43 \%$ de discordantes. Contudo, apresentou padrão de resposta distinto quanto à dimensão Padrões éticos, onde a maior incidência foi de discordantes, com $38 \%$.

Tabela 6: Confiança na Organização - Frequência (Empresa B)

\begin{tabular}{|c|c|c|c|c|c|c|c|}
\hline & & & $\begin{array}{l}\text { Promoção do } \\
\text { crescimento do } \\
\text { empregado }\end{array}$ & \begin{tabular}{|c|} 
Reconhecimento \\
financeiro \\
organizacional
\end{tabular} & $\begin{array}{c}\text { Solidez } \\
\text { organizacional }\end{array}$ & Padrões éticos & \begin{tabular}{|c|} 
Normas relativas \\
à demissão de \\
empregados
\end{tabular} \\
\hline Discordância & $\begin{array}{l}\text { Escore } \\
\text { Médio } \\
\text { até 2,9 }\end{array}$ & $\%$ & $\begin{array}{r}58 \\
26 \%\end{array}$ & $\begin{array}{r}57 \\
26 \%\end{array}$ & $\begin{array}{r}52 \\
23 \%\end{array}$ & $\begin{array}{c}84 \\
38 \%\end{array}$ & $\begin{array}{r}96 \\
43 \%\end{array}$ \\
\hline Indiferença & $\begin{array}{c}\text { Escore } \\
\text { Médio } \\
\text { entre } 3 \\
\text { e } 3,9\end{array}$ & $\%$ & $\begin{array}{c}87 \\
39 \%\end{array}$ & $\begin{array}{c}94 \\
42 \%\end{array}$ & $\begin{array}{r}99 \\
45 \%\end{array}$ & $\begin{array}{r}82 \\
37 \%\end{array}$ & $\begin{array}{c}90 \\
41 \%\end{array}$ \\
\hline Concordância & $\begin{array}{c}\text { Escore } \\
\text { Médio } \\
\text { entre } 4 \\
\text { e } 5\end{array}$ & $\mathrm{~N}$ & $\begin{array}{c}77 \\
35 \%\end{array}$ & $\begin{array}{c}71 \\
32 \%\end{array}$ & $\begin{array}{c}71 \\
32 \%\end{array}$ & $\begin{array}{r}56 \\
25 \%\end{array}$ & $\begin{array}{c}36 \\
16 \%\end{array}$ \\
\hline
\end{tabular}

Fonte: Dados da pesquisa

O que chama a atenção em relação ao padrão de resposta das duas empresas diz respeito ao alto percentual de respondentes indiferentes. $\mathrm{Na}$ empresa $A$, isso ocorreu em três das cinco dimensões e, na empresa $B$, essa ocorrência foi verificada em quatro das cinco dimensões. De acordo com Collings (2006), esse fenômeno é comum em escalas de Likert, de cinco pontos, onde a existência do ponto neutro ("Nem concordo, nem discordo") pode gerar ambivalência e indiferença do respondente, destoando à verdadeira opinião do respondente.

A tabela 7 foi construída através do agrupamento das variáveis em fatores determinados por Oliveira e Tamayo (2008). 
Tabela 7: Confiança na Organização - Escore Médio

\begin{tabular}{|c|c|c|c|}
\hline \multirow{2}{*}{ Dimensões: } & \multirow{2}{*}{ Itens } & \multicolumn{2}{|c|}{ Escore Médio } \\
\hline & & Empresa A & Empresa B \\
\hline Promoção do crescimento do empregado & 5 & 4,1 & 3,6 \\
\hline Solidez organizacional & 6 & 4,2 & 3,6 \\
\hline Reconhecimento financeiro organizacional & 5 & 3,5 & 3,3 \\
\hline Padrões éticos & 5 & 3,9 & 3,5 \\
\hline Normas relativas à demissão de empregados & 7 & 2,6 & 2,8 \\
\hline
\end{tabular}

Fonte: Dados da pesquisa

\subsection{1.}

\section{Promoção do Crescimento do Empregado}

Ao calcular o escore médio das dimensões para toda a amostra, percebese que a empresa A apresentou um grau de concordância na dimensão Promoção do crescimento do empregado, com escore médio de 4,1. Já o resultado da empresa $B(3,6)$ indicou que os trabalhadores se mostram indiferentes, não confiam nem desconfiam do incentivo ao crescimento profissional dos empregados por meio de alternativas concretas e reais propostas pela organização. O resultado vai ao encontro de estudos empíricos apresentados, que consideram o crescimento do empregado um importante preditor da rotatividade (STEERS \& MOWDAY, 1981; MOBLEY, 1992; SPECTOR, 2002; RAMLALL, 2003).

De acordo com o constructo de Oliveira e Tamayo (2008, p.102), o fator Crescimento e promoção do empregado na organização está relacionado com o "incentivo ao crescimento profissional dos empregados por meio de alternativas concretas e reais propostas pela organização, permitindo aos colaboradores prever seu crescimento naquele contexto de trabalho."

Segundo Oliveira e Tamayo (2008), a confiança do empregado em relação às possibilidades reais de crescimento profissional é um dos aspectos que pode promover o engajamento do indivíduo com o trabalho, sendo este muito positivo para o trabalhador já que irá possibilitar um sentimento de auto-valor aumentando a confiança dele sobre suas habilidades e competências profissionais.

Robbins (2002) identificou que os trabalhadores procuram seus trabalhos de forma compatível com seus interesses, valores e habilidades e os 
funcionários que apresentam um melhor desempenho, permanecem por mais tempo na organização devido ao seu reconhecimento e possibilidade de crescimento.

As oportunidades de crescimento promovidas pela empresa podem ter influência sobre a motivação do trabalhador, e ainda influenciar sobre a percepção dos funcionários no que se refere a segurança que sentem no serviço, que não está ligada apenas as oportunidades de crescimento, mas também a permanência na organização, influenciando diretamente a rotatividade das empresas (SIQUEIRA, 2004).

Diante do exposto, é possível pressupor que o fato da empresa $A$ ter demonstrado um grau de concordância com a dimensão Promoção do crescimento do empregado, enquanto os respondentes da empresa $B$ mostraram-se indiferentes a essa dimensão, pode ser um dos fatores que explicam a rotatividade mais baixa verificada na empresa $A$ nos últimos anos, conforme demonstrado na sessão 4.1.

\subsection{2.}

\section{Solidez Organizacional}

Com relação à dimensão Solidez organizacional, observou-se que a empresa A apresentou grau de concordância, com escore médio de 4,2. A análise das respostas da empresa $B$, por sua vez, indicou indiferença, com escore médio de 3,6. Tal resultado vai de acordo com achados empíricos apresentados nesse estudo, que consideram a estabilidade financeira da organização como um dos aspectos causadores da rotatividade (STEERS \& MOWDAY, 1981; MOBLEY, 1992; TETT \& MEYER (1993); WRIGHT \& KEHOE, 2009; RAMLALL, 2003).

Esse resultado também pode ser considerado esperado, visto que a solidez organizacional ou competência organizacional é encontrada como dimensão da confiança em vários estudos (HOSMER, 1995; MCALLISTER, 1995; MAYER et al., 1995; DIRKS \& FERRIN, 2001).

Para Oliveira e Tamayo (2008, p.102), o fator solidez organizacional "refere-se à firmeza, à estabilidade financeira da organização, cujos reflexos são o cumprimento de suas obrigações financeiras com os empregados, o pagamento de salário pontualmente, a perspectiva de um futuro próspero, bem como a capacidade de superar crises econômicas ocasionadas por planos governamentais e mudanças de mercado". 
Pode-se afirmar que os empregados possuem confiança na solidez organizacional quando estes percebem que a empresa adota estratégias de forma consistente, visando sua longevidade. Outro indicador de confiança que pode ser percebido é quando os empregados entendem que a organização está bem posicionada no mercado e que seus pagamentos serão efetuados nas datas previstas. (OLIVEIRA \& TAMAYO, 2008).

Portanto, pode-se pressupor que o fato da empresa $A$ ter demonstrado confiança na dimensão Solidez organizacional, enquanto os respondentes da empresa B mostraram-se indiferentes a essa dimensão, pode ajudar a explicar a rotatividade mais baixa verificada na empresa $A$ nos últimos anos, conforme demonstrado na sessão 4.1. De acordo com Ramlall (2003), a reputação da empresa e o compromisso em manter os contratos firmados estão entre os fatores mais significativos que influenciam a decisão do empregado em permanecer na organização.

\subsection{3.}

\section{Reconhecimento Financeiro Organizacional}

Já em relação à dimensão Reconhecimento financeiro da organização, observou-se que tanto a empresa $A$ quanto a empresa B apresentaram grau de indiferença em relação a confiança nesta dimensão, com escores médios bastante semelhantes, de 3,5 e 3,3, respectivamente. Pode-se afirmar que esse resultado corrobora a literatura apresentada no presente estudo, que é praticamente unânime quanto a representatividade do reconhecimento financeiro em relação a rotatividade (PRICE, 1977; STEERS \& MOWDAY, 1981; MOBLEY, 1992; RAMLALL, 2003).

Oliveira e Tamayo (2008) apontam que o fator reconhecimento financeiro organizacional diz respeito ao reconhecimento e valorização financeira dos esforços do empregado, principalmente por meio de salário. A concessão de aumento salarial é percebida como uma das manifestações de reconhecimento por parte da organização. Esse reconhecimento financeiro beneficia ambas as partes e é um dos principais fatores de retenção.

No mesmo sentido, Ramlall (2003) considera o salário uma questão importante quando se trata de retenção do empregado, pois ele está diretamente ligado à satisfação das necessidades básicas do trabalhador. Quanto à política salarial, observa-se que ela é um fator importante no estudo da rotatividade, visto que baixos salários podem induzir os funcionários a buscarem outra empresa. Quando a organização consegue atender através do salário as 
necessidades e expectativas dos trabalhadores, ela permite que fortes vínculos sejam criados nesta relação empresa x funcionário (SIQUEIRA, 2004).

Assim, um empregado que apresenta confiança quanto ao reconhecimento financeiro da organização, segundo os estudos expostos, tende a permanecer na organização. Contudo, os resultados não foram significativos a ponto da dimensão Reconhecimento financeiro da organização ser elencada como um dos aspectos que ajuda a explicar a rotatividade mais baixa da empresa $A$, uma vez que houve indiferença dos respondentes de ambas as empresas quanto a dimensão em questão.

\subsection{4.}

\section{Padrões Éticos}

Na dimensão Padrões Éticos, o escore médio obtido pela empresa $A$ foi de 3,9 , enquanto que a empresa $B$ apresentou um resultado de 3,5. Demonstrando que os empregados de ambas as empresas são indiferentes aos princípios éticos como honestidade, igualdade, lealdade, transparência da organização ao divulgar informações, responsabilidade, manutenção de compromissos e respeito.

Os vínculos formados entre empregado e organização são estabelecidos através dos valores organizacionais internalizados pelos trabalhadores, e o envolvimento deles com as metas e ocupações pertinentes ao seu cargo. A ética é um antecedente direto da compreensão acerca da justiça de procedimentos formais e de procedimentos de interação que irão se configurar como vínculos organizacionais (RAMACCIOTTI, 2007).

Confiar diz respeito à expectativa de uma pessoa, grupo ou empresa de adotar comportamentos eticamente justificáveis, ou seja, ações e decisões moralmente corretas, pautadas em princípios éticos. Deste modo, entende-se que confiança e ética são temas entrelaçados (HOSMER, 1995).

Os estudos apresentados (MAYER et al., 1995; HOSMER, 1995) apresentam forte presença dos componentes éticos alinhados à confiança. Dessa forma, a percepção do empregado a respeito das ações da organização, é caracterizada por componentes éticos como respeito, lealdade, benevolência, sinceridade.

Pode-se afirmar que esse resultado vai ao encontro com estudos analisados, constatando a estreita relação entre confiança e princípios éticos (STEERS \& MOWDAY, 1981; HOSMER, 1995; MAYER et al., 1995). Contudo, os resultados não foram significativos para que a dimensão Padrões éticos 
possa ser apontada como um dos aspectos que ajuda a explicar a rotatividade mais baixa da empresa $A$, uma vez que houve indiferença dos respondentes de ambas as empresas quanto a dimensão em questão.

\subsection{5.}

\section{Normas Relativas à Demissão de Empregados}

Dentre todas as dimensões a que apresentou escores médios mais baixos foi Normas relativas à demissão dos empregados com 2,6 para a empresa $\mathrm{A} e$ 2,8 para a empresa $B$, demonstrando que há discordância por parte dos trabalhadores com as normas organizacionais definidas para a demissão dos empregados que permitem ou não a eles preverem sua permanência na organização. Tal resultado vai de encontro a grande parte da literatura analisada, que considera que normas organizacionais bem definidas e implementadas de forma transparente são importantes para a redução da rotatividade (PRICE, 1977; STEERS \& MOWDAY, 1981; SPECTOR, 2002; RAMLALL, 2003; WRIGHT $\&$ KEHOE, 2009).

De acordo com Oliveira e Tamayo (2008) a dimensão diz respeito à presença ou ausência de normas organizacionais definidas para a demissão dos empregados, permitindo, ou não, ao empregado prever sua permanência na organização. Para Spector (2002), a percepção de justiça nos procedimentos é um fator importante no aumento da confiança, destacando a relevância na implementação de atitudes justas nos procedimentos organizacionais relacionados às normas de demissão de empregados.

A falta de clareza nas normas utilizadas na demissão dos funcionários está inversamente ligada com a satisfação, ao envolvimento com o trabalho e também ao comportamento afetivo na organização, aumento a possibilidade de saída do empregado (OLIVEIRA \& TAMAYO, 2008).

De acordo com o exposto, pode-se pressupor que a dimensão Normas relativas a demissão não ajuda a explicar a rotatividade mais baixa apresentada pela empresa A, uma vez que os respondentes de ambas as empresas apresentaram discordância em relação a essa dimensão.

\subsection{6.}

\section{A Influência da Rotatividade nas Cinco Dimensões}

Esperava-se, com base na literatura que trata da relação entre os conceitos confiança organizacional e rotatividade e, diante da premissa proposta no presente estudo, que a empresa $A$ apresentasse resultados superiores aos 
mostrados pela empresa $B$, a respeito das cinco dimensões propostas por Oliveira e Tamayo (2008), quais sejam: Promoção do crescimento do empregado, Solidez organizacional, Reconhecimento financeiro organizacional, Padrões éticos e Normas relativas à demissão de empregados.

Contudo, a correlação entre a rotatividade das empresas e a confiança organizacional foi verificada de maneira consistente apenas em relação a Promoção do crescimento do empregado e Solidez organizacional. As dimensões Reconhecimento financeiro organizacional e Padrões éticos mostraram-se indiferentes na relação com a rotatividade das empresas. Já a dimensão Normas relativas à demissão de empregados apresentou indícios de uma correlação negativa com a rotatividade observada nas empresas analisadas, o que significa até inferir que quanto maior a clareza das normas e mecanismos de demissão o empregado possuir, maior será a rotatividade da empresa.

De acordo com as relações estudadas, a maioria das dimensões analisadas impactam positivamente ou são indiferentes em relação a rotatividade, portanto pode-se pressupor que há uma relação positiva entre os dois constructos e concluir que é verdadeira a premissa "O constructo confiança organizacional impacta positivamente o índice de rotatividade das empresas de ônibus" proposta nesse estudo. 


\section{6 Conclusão e Recomendações}

O objetivo principal deste trabalho é analisar o impacto da confiança organizacional nos níveis de rotatividade e absenteísmo das empresas de transporte de passageiros.

Os dados coletados junto a 385 colaboradores da empresa A e 222 colaboradores da empresa $\mathrm{B}$, quando analisados à luz do referencial teórico, permite encontrar contribuições significativas a Literatura sobre os conceitos e suas relações no contexto organizacional, tornando possível indicar respostas aos objetivos e premissas propostas.

Assim, a resposta ao objetivo principal se confirma por meio da observação dos dados obtidos através da pesquisa de campo, verificando que há influência positiva do constructo confiança nos níveis de rotatividade das empresas.

Contudo, não foi possível pressupor a influência positiva da confiança em relação ao absenteísmo das empresas, uma vez que não há elementos que confirmem a relação entre absenteísmo e as cinco dimensões da confiança do modelo de Oliveira e Tamayo (2008).

Os objetivos intermediários - relacionados à conceituação do tema proposto, à identificação de seus principais constructos e instrumentos de medição e ao estudo de caso comparativo propriamente dito - também foram atingidos. A revisão da literatura permitiu que fossem analisados os principais fundamentos teóricos desenvolvidos sobre confiança organizacional e rotatividade.

Com relação à primeira premissa proposta para esta pesquisa: $O$ constructo confiança organizacional impacta positivamente 0 índice de rotatividade, o presente estudo concluiu que (1) quanto maior for a confiança na promoção do crescimento do empregado e na solidez organizacional, menor serão os níveis de rotatividade das empresas; (2) as relações entre reconhecimento financeiro organizacional e padrões éticos com a rotatividade são neutras; (3) normas relativas à demissão de empregados não influenciam diretamente os níveis de rotatividade e absenteísmo das organizações. 
Com isto, de acordo com as relações estudadas, a maioria das dimensões de confiança organizacional analisadas impacta positivamente ou são indiferentes em relação à rotatividade, portanto pode-se pressupor que há uma relação positiva entre os constructos e concluir que o constructo confiança organizacional impacta positivamente o índice de rotatividade das empresas de transporte de passageiros.

É importante ressaltar que os resultados aqui encontrados não podem ser generalizados para diferentes populações, já que foi realizado um estudo de caso comparativo e os resultados se limitam aos participantes desta pesquisa, porém, podem servir como indicações de possíveis linhas de ação para outras empresas, ou até mesmo dentro das organizações analisadas, buscando ampliála. Também pode contribuir para que novas pesquisas empíricas sejam realizadas para analisar a relação entre confiança organizacional, absenteísmo e rotatividade, pois ainda são escassos na literatura.

Sugere-se a realização de estudos que relacionem confiança organizacional com intenção de deixar a empresa, deste modo, seria possível fazer uma análise complementar a que foi apresentada no presente estudo, com a utilização de uma variável dependente para o modelo. 


\section{7 \\ Referências bibliográficas}

ABELSON, M. A.; BAYSINGER, B. D. Optimal and Dysfunctional Turnover: Toward an Organizational Level Model. Academy of Management Review, 1984.

ARRANZ, J. M., \& DAVIA, M. A. Worker turnover and wages in europe: the influence of unemployment and inactivity. The Manchester School, n. 78, p. 678-701, 2010.

BABBIE, E. R. Métodos de pesquisas de survey. Belo Horizonte: Editora da UFMG, 1999.

BATTISTON, M.; CRUZ, R. M.; HOFFMANN, M. H. Condições de trabalho e saúde de motoristas de transporte coletivo urbano. Estudos de Psicologia, $v$. 11, n. 3, p. 333-343, 2006.

BERNSTORFF, V. H.; DAL ROSSO, S. O absenteísmo ao trabalho como forma de resistência à intensificação do trabalho, à insatisfação profissional e ao estresse ocupacional. In: XXXII ENCONTRO DA ANPAD, n. 32, Rio de Janeiro, 2008.

BIGLEY, G. A.; PEARCE, J. L. Straining for shared meaning in organization science: Problems on trust and distrust. Academy of Management Review, v. 23, n. 3, p. 405-421, 1998.

BLAU, P. M. Power and Exchange in Social Life. New York: Wiley, 1964.

BLUEDORN, A. C. A taxonomy of turnover. Academy of Management Review, July, p. 647-651, 1978.

BOOTH, C.; ROWLINSON, M. Management and organizational history: prospects. Management \& Organizational History, London, v.1, n.1, p. 5-30, 2006.

BORGES, L. C. Principais causas da rotatividade de pessoal em uma empresa de construção civil de Criciúma SC, e quais os reflexos para a empresa. Trabalho de Conclusão do Curso de Ciências Contábeis. Universidade do Extremo Sul Catarinense - UNESC. Criciúma - SC, 2011.

BRIEF, A. P.; WEISS, H. M. Organizational behavior: affect in the workplace. Annual Reviews Psychology, n. 53, p. 279-307, 2002.

BRYMAN, A. Research methods and organization studies. London: Unwin Hyman, London, 1989.

CAETANO, A.; NEVES, P. Social exchange processes in organizational change: The roles of trust and control. Journal of Change Management, 2006. 
CAETANO, A.; SOUSA-LIMA. Importância do papel mediador da confiança nas organizações: relações de troca social e satisfação no trabalho, v. 3, pp. 145-157, 2007.

CAMPOS, C. V. A.; MALIK, A. M. Satisfação no trabalho e rotatividade dos médicos do Programa de Saúde da Família. Revista de Administração Pública, v. 42, n. 2, p. 347-368, 2008.

CASCIO, W. Costing Human Resources: The Financial Impact of Behavior in Organizations. 3rd. Ed. Boston: PWS-KENT Publishing Company (Kent human resource management series), 1991.

CAVALCANTI, V. L. Subsídios técnicos que justifiquem a manutenção da aposentadoria especial para motoristas de ônibus urbano. São Paulo, 1996.

CHAUDHURY, M.; NG, I. Absenteeism predictors: least squares, rank regression, and model selection results. The Canadian Journal of Economics, v. 25, n.3, p. 615-635, 1992.

CHAHAD, J.P.Z. Mercado de trabalho: conceitos, definições e funcionamento. In D. B. Pinho \& M. A. S. Vasconcellos (Orgs.), Manual de Economia, v. 5, p. 381-405, São Paulo: Saraiva, 2006.

CHANG, E. Career commitment as a complex moderator or organizational commitmentand turnover intention. Human Relations, v. 52, p. 1257-1278, 1999.

COLLINGS, D. P. Selecting a questionnaire response scale for student feedback surveys: a comparison of psychometric properties and student preferences among three alternatives. Master dissertation. Murdoch University. 2006.

COOK, J.; WALL, T. New work attitude measures of trust, organizational commitment, and personal need nonfulfillment. Journal of Occupational Psychology, n. 53, p. 39-52, 1980.

COSTA, A. C. Estudos organizacionais: novas perspectivas na administração de empresas: uma coletânea luso-brasileira, São Paulo: Iglu Editora Ltda, p. 284-305, 2000.

COSTA, A.M.; BARROS, D.F.; MARTINS, P.E.M. Perspectiva histórica em administração: panorama da literatura, limites e possibilidades. In: XXXIII ENCONTRO DA ANPAD, São Paulo, 2009.

COSTA, A.M.; SARAIVA, L. A. S. Memória e formalização social do passado nas organizações. Revista de Administração Pública, Rio de Janeiro, v. 45, n. 6, p. 1761-1780, 2011.

CUMMINGS, L. L.; BROMILEY. Organizational Responses to Crisis: The Centrality of Trust. In: In: Trust in Organizations: Frontiers of Theory and Research. KRAMER, R. M.; TYLER, T. R. (Org). Thousand Oaks: Sage Publications, 1996.

DAS, T. K.; TENG, B. S. Trust, Control and Risk in Strategic Alliances: An Integrated Framework. Organization Studies, v. 22, p. 251-83, 2001. 
DALTON, D.; MESCH, D. On the extent and reduction of avoidable absenteeism: An assessment of absence policy provisions. Journal of Applied Psychology, v. 76, n. 6 , p. $810-817,1991$.

DALTON, D.R.; TODOR, W. D. Turnover: a lucrative hard dollar phenomenon. Academy of Management Review, v. 7, n. 2, p. 212-218, 1982.

DAVIA, M. A. Job mobility and wage mobility at the beginning of the working career: a comparative view across Europe. Working paper of the Institute for Social and Economic Research, University of Essex, 2005.

DAVIS, K.; NEWSTROM, J. W. Comportamento humano no trabalho: uma abordagem psicológica. São Paulo: Pioneira, 1996.

DEUTSCH, M. Trust and suspicion. Journal of Conflict Resolution, n. 2, p. 265-279, 1958.

DIAS, A. M. N. Absenteísmo nas empresas. UNICEUB, Centro Universitário de Brasília, 2006.

DIEESE. Estudo setorial da construção 2011. Estudos \& Pesquisas, São Paulo, 2011.

DIEESE. Estudo setorial da construção 2014. Estudos \& Pesquisas, São Paulo, 2014.

DIRKS, K. T. The effects of interpersonal trust on work group performance. Journal of Applied Psycology, n. 84, p. 445-455, 2001.

DONEY, P.M.; CANNON, J.P. An examination of the nature of trust in buyerseller relationships. Journal of Marketing, v. 61, n. 2, 1997.

ETZIONI, A. Sociologia industrial: o estudo das organizações econômicas. Organizações complexas. São Paulo: Atlas, 1981.

FERREIRA, M. L. C. B. Modelo Psicossocial para intenção de rotatividade: estudo comparativo entre trabalhadores dos setores metalúrgicos e eletroeletrônico. 86 f. Dissertação (Mestrado em Administração) - Programa de Pós Graduação em Administração, Universidade Metodista de São Paulo, São Paulo, 2001.

FERREIRA, M. C.; FREIRE, O. N. Carga de Trabalho e Rotatividade na Função de Frentista. Revista de Administração Contemporânea, Curitiba, v. 5, n. 2, p. 175-200, 2001.

FIALA, R.; PROKOP, M.; ZIVELOVÁ, I. The relationship between interorganizational trust and performance. Acta Universitatis Agriculturae et Silviculturae Mendelianae Brunensis, v. 60, n. 4, p. 89-98, 2012.

FISHER, R., NOVELLI, J. Confiança como fator de redução da vulnerabilidade humana no ambiente de trabalho. Revista de Administração de Empresas, v. 48, p. 67-77, 2008.

FUKUYAMA, F. Confiança: as virtudes sociais e a criação da prosperidade. 
Rio de Janeiro, Rocco, p. 455, 1996.

GANESAN, S.; HESS, R. Dimensions and Levels of Trust: Implications for Commitment to a Relationship. Marketing Letters, p. 439-48, 1994.

GIDDENS, A. As conseqüências da modernidade. São Paulo, Editora da Unesp, 1991.

GIL, Antonio Carlos. Como elaborar projetos de pesquisa. São Paulo: Atlas, 2010.

GILBERT, J. A.; TANG, T. Li-Ping. An examination of organizational trust antecedents. Public Personnel Management, v. 27, n. 3, p. 321-338, 1998.

GILLESPIE, N. Measuring trust in working relationships: the behavioral trust inventory. Journal of Applied Psychology, Melbourne, Australia: University of Melbourne, 2003.

GODOY, A. S. Pesquisa qualitativa: tipos fundamentais. Revista de Administração de Empresas, São Paulo, v. 35, n. 3, p. 20-29, 1995.

GONZAGA G. Rotatividade e qualidade do emprego no Brasil. Revista brasileira de economia política, v. 18, n. 69, p. 120-140, 1998.

HAMEL, L; VÄLIKANGAS, L. The Quest for Resilience. Harvard Business Review, v. 81, n. 9, p. 56-63, 2003.

HARRISON, D. A.; MARTOCCHIO, J.J. Time for absenteeism: A 20-year review of origins, offshoots, and outcomes. Journal of Management, p. 305-350, 1998.

HAUSKNECHT, J. P.; HOLWERDA, J. A. When does employee turnover matter? Dynamic member configurations, productive capacity, and collective performance. Organization Science, v. 24, n. 1, p. 210-225, 2013.

HOLLENBECK, J. R.; WILLIAMS, C. R. Turnover functionality versus turnover frequency: a note on work attitudes and organizational effectiveness. Journal of Applied Psychology, v. 71, n. 4, p. 606-611, 1986.

HOSMER, L. T. The Connecting Link between Organizational Theory and Philosophical Ethics. The Academy of Management Review, v. 20, n. 2, p. 379403, 1995.

IPEA/ANTP. Redução das deseconomias urbanas com a melhoria nos transportes públicos. Brasília: Ipea, 1998.

JEFFRIES, F.L. Trust and adaption in relational contracting. Academy of Management Review, 2000.

JOHNS, G. How methodological diversity has improved our understanding of absenteeism from work. Human Resource Management Review, v. 13 (2), p. 157-184, 2003.

JOHNSON, J. L.; O'LEARLY-KELLY, A. M. The effects of psychological contract breach and organizational cynicism: not all social exchange violations are created equal. Journal of Organizational Behavior, v. 24, p. 627-647, 2003. 
KEE, H. W.; KNOX, R. E. Conceptual and Methodological Considerations in the Study of Trust and Suspicious. Journal of Conflict Resolution, n. 14, p. 357366, 1970.

KIMBROUGH, Ralph B. Princípios e Métodos de Administração Escolar. São Paulo: Ed. Saraiva, 1997.

KRAMER, R. Trust and Distrust in Organizations: Emerging Perspectives, Annual Review of Psychology, v. 50, p. 569-598, 1999.

KRAMER, R. M.; TYLER, T.R. Trust in organizations: frontiers of theory and research. Thousand Oaks: Sage Publications, 1996.

LANGER, E. J. The illusion of control. Journal of Personality and Social Psychology, v. 32, p. 311-328, 1975.

LEBLEBICI, H.; SHAH, N. The birth, transformation and regeneration of business incubators as new organizational forms: understanding the interplay between organizational history and organizational theory. Business History, v. 46, n. 3, p. 353-380, 2004.

LEE, H. R. A. Empirical study of organizational justice as a mediator of the relationships among leader member exchange and job satisfaction, organizational commitment and turnover intentions in the lodging industry. Virginia: Virginia PIS University, 2000.

LEE, T. W.; MOWDAY, R. T. Voluntarily leaving an organization: an empirical investigation of Steers and Mowday's modelo $f$ turnover. Academy of Management Journal, v. 30 (4), p. 721-743, 1987.

LEWICKI, R. J.; BUNKER, B. B. Trust in Relationships: A Model of Trust Development and Decline. Max M. Fisher College of Business, Ohio State University, 1994.

LEIRIA, A. C.; PALMA, P. J.; PINHA E CUNHA, M. O contrato psicológico em organizações empreendedoras: Perspectivas do empreendedor $e$ da equipe, Comportamento organizacional e gestão, vol. 12, n. 1, p. 67-94, 2002.

LUNDÄSEN, S. Podemos confiar nas medidas de confiança? Porto Alegre: Artmed, 2008.

LUHMANN, N. Ilustración Sociológica y Otros Ensayos. Sur, Buenos Aires, 1996.

MARIM, S. P. Absenteísmo dos funcionários do setor de construção civil do estado do Espírito Santo. 2012. 72 p. Dissertação (Mestrado em Administração). Programa de Pós-Graduação em Administração de Empresas, Instituto de Pesquisa em Contabilidade, Economia e Finanças, Vitória, 2012.

MARIOTTI, T. Investment timing and learning externalities, Journal of Economic Theory, 2004.

MARCONI, M. A.; LAKATOS, E. M. Fundamentos da metodologia científica. 6 
ed. São Paulo: Atlas, 2005, p. 203.

MATTAR, F. N. Pesquisa de marketing: edição compacta. São Paulo: Atlas, 1996.

MAYER, R. C.; DAVIS, J. H.; SCHOORMAN, F. D. An Integrative Model of Organizational Trust. The Academy of Management Review, v. 20, n. 3, p. 709734, 1995.

MAXIMIANO, A. C. A teoria geral da administração. São Paulo: Atlas, 1997.

MCALLISTER, D. J. Affect and Cognition-Based Trust as Foundations for Interpersonal Cooperation in Organizations. Academy of Management Journal, v. 38, n. 1, p. 24-59, 1995.

MCEVILY, B. Reorganizing the Boundaries of Trust: From Discrete Alternatives to Hybrid Forms. Organization Science, v. 22(5), 2011.

MCDONALD, J. M.; SHAVER, A. V. An absenteeism central program. Journal of Nursing Administration, v. 11, n. 5, p. 13-18, 1981.

MCKNIGHT, D; CUMMINGS, L.; CHERVANY, N. Initial Trust Formation in New Organizational Relationships. The Academy of Management Review, v. 23, n. 3, p. 473-490, 1998.

MEDEIROS, C. R. G.; JUNQUEIRA, A. G. W.; SCHWINGEL, G.; CARRENO, I.; JUNGLES, L. A. P.; SALDANHA, O. M. F. L. A rotatividade de enfermeiros e médicos: um impasse na implementação da Estratégia de Saúde da Família. Ciência e Saúde Coletiva, v. 15 (1), p. 1521-1531, 2010.

MILKOVICH, G. T.; BOUDREAU, J. W. Administração de Recursos Humanos. São Paulo: Atlas, 2000.

MINTZBERG, H.; LAMPEL, J. Reflecting on the strategy process. Sloam Management Review, p. 21-30, 1999.

MOBLEY, W. H. Turnover: causas, consequências e controle. Porto Alegre: Ortiz, 1992.

MORESI, E. A. D. Manual de Metodologia da Pesquisa. Brasília-DF: Universidade Católica de Brasília - UCB, 2003.

MORREL, K.; LOAN-CLARKE, J.; WILKINSO, A. Unweaving Leaving: The Use of Models in the Management of Turnover. International Journal of Management Reviews, v. 3, n. 3, p. 219-244, 2001.

OLIVEIRA, A. F. Confiança do empregado na organização: impacto dos valores pessoais, organizacionais e da justiça organizacional (Tese de Doutorado não publicada). Universidade de Brasília, DF, 2004.

OLIVEIRA, A. F.; TAMAYO, A. Confiança do empregado na organização. Porto Alegre: Artmed Bookman, p. 97-110, 2008.

PALMATIER, R. W.; DANT, R. P.; A Comparative Longitudinal Analysis of Theoretical Perspectives of Interorganizational Relationship Performance. 
Journal of Marketing. v. 71, p. 172-194, 2007.

PARK, T.; SHAW, J. D. Turnover rates and organizational performance: a metaanalysis. Journal of Applied Psychology, v. 98, n. 2, p. 268-309, 2013.

PEREIRA, A. S. Confiança e Desempenho Individual: Um Estudo de Caso em uma Empresa do Setor Cimenteiro. Caderno de Saúde Pública, v. 21, n. 2, p. 436-448, 2008.

PHILLIPS, J. J.; CONNELL, A. O. Managing Employee Retention: A Strategic Accountability Approach. Burlington, MA: Elsevier, 2003.

PONTES, B. R. Planejamento, recrutamento e seleção de pessoas. 3. ed. São Paulo: LTr, 2001.

PRICE, J. L. The study of turnover. lowa: The lowa State University Press, 1977.

PONTES, B. R. Planejamento, recrutamento e seleção de pessoas. 3. ed. São Paulo: LTr, 2001.

PricewaterhouseCoopers. Tendências em capital humano - Retenção de Talentos, 34p., 2011. Disponível em http://www.pwc.com.br/pt_BR/br/estudospesquisas/assets/relat-retencao/talentos-11a.pdf, Acesso em 23-out-2015.

RAMLALL, $S$. Managing employee retention as a strategy for increasing organizational competitiveness. Applied H. R. M. Research, v. 8, n. 2, p. 6372, 2003.

RAMOS, R. E. B. Condições de trabalho dos motoristas de ônibus: uma contribuição a uma abordagem interdisciplinar com estudo de caso no Rio de Janeiro, Mestrado em psicologia - Universidade Federal do Rio de Janeiro, 1991.

RIBEIRO, E. P. Rotatividade de trabalhadores e criação e destruição de postos de trabalho: aspectos conceituais [Texto para discussão, $N^{\circ} 820$ ]. Rio de Janeiro, RJ: IPEA, 2001.

ROBBINS, S. Fundamentos do Comportamento Organizacional, São Paulo: Ed. Prentice Hall, 2002.

ROBBINS, S.P. Comportamento organizacional ( $8^{a}$ ed.). Rio de Janeiro: LTC Editora, 1999.

RAMACCIOTTI, C. A Ética e a Confiança nas Organizações: um estudo descritivo junto a profissionais da Grande São Paulo. Tese de Doutorado. Fundação Getúlio Vargas, 2007.

ROUSSEAU, D. M.; SITKIN, S. B.; BURT, R. S.; CAMERER, C. Not so different after all: A cross-discipline view of trust. Academy of Management Review, $v$. 23, p. 393-404, 1998.

ROTTER, L. A new scale for the measurement of interpersonal trust, Journal of Personality, p. 35, 1967. 
SATO, C. T. Gestão baseada em relações de confiança. Eletrônica - v. 2, n. 1, 2003.

SCHINDLER, P. L.; THOMAS, C. C. The structure os interpersonal trust in workplace. Psychological Reports, v. 73, n. 2, p. 563-573, 1993.

SCHOCKLEY-ZALABAK, P.; ELLIS, K.; WINOGRAD G. Organizational trust: what it means, why it matters. Organization Development Journal, v. 18, n. 4, p. 35-48, 2000.

SIQUEIRA, M. M. M.; GOMIDE, JR. S.. Vínculos do indivíduo com o trabalho e com a organização. In:ZANELLI, J. C.; BORGES-ANDRADE, J. E.; BASTOS, A. V. B. Psicologia, organizações e trabalho no Brasil. Porto Alegre: Artmed, 2004.

SIQUEIRA, M. M. M; PEREIRA, S. E. F. N. Análise de um modelo afetivo para intenção de sair da organização. Revista da STPM, p. 48-57, 2001.

SIQUEIRA, M. M. M; PEREIRA, S. E. F. N. Antecedentes de intenção de rotatividade: estudo de um modelo psicossocial. Organizações em contexto, Ano 1, n. 2, 2005.

SPECTOR, P. E. Psicologia nas Organizações. São Paulo: Saraiva, 2002.

SPINK, M. J. P. Trópicos do discurso sobre risco: risco-aventura como metáfora na modernidade tardia. Cad. Saúde Pública, Rio de Janeiro, 2001.

SOUSA-POZA, A.; HENNEBERGER, F. Analysing job mobility with job turnover intentions: an international comparative study. Journal of Economic Issues, $v$. 38, n. 1, p. 113-137, 2004.

STARK, J. B. Trust Development: A Test of Image Theory to Explain the Process. Dissertação de Doutorado em Filosofia, Universidade do Missouri, Columbia, Dezembro, 2001.

STEEL, R.P. Methodological and operational issues in the construction of absence variables. Human Resource Management Review, v. 13, n. 2, p. 243251, 2003.

STEERS, R. M.; MOWDAY, R. T. Employee turnover and post-decision accomodation process. In L. Cummings \& B. Staw (Eds.), Research in organization behavior (v. 3). Greenwich, Connecticut: JAI Press, 1981, PP.235281, 1981.

SYDOW, J. Understanding the constitution of interorganizacional trust. Oxford: Oxford University Press, cap.1, 1998.

TAMAYO, A. Valores Organizacionais: sua relação com satisfação no trabalho, cidadania organizacional e comprometimento afetivo. Revista de Administração de Empresas, v. 33, n. 3, p. 56-63, 1998.

TETT, R. P.; MEYER, J. P. (1993). Job satisfaction, organizational commitment, turnover intention, and turnover: path analyses based on meta-analytic findings.

Personnel psychology, v. 46, n. 2, p. 259-293. 
TOMEI, P. A.; LANZ, L. Q. (2015). Confiança nas Organizações. 1aㅡ. ed. Rio de Janeiro. Elsevier, PUC-Rio, p. 248.

TZAFRIR, S. S.; HAREL, G. H. Trust-ME: A scale for measuring manager employee trustworthiness. Academy of Management. Mississipi State, v. 45, n. 4. 2002.

TZAFRIR, S. S.; DOLAN; S. L. Trust me: a scale for measuring manageremplyee trust. Management Research, v. 2, p. 115-131, 2004.

VANDENBERG, R. J. Desegregating the Motives Underlying Turnover Intentions: When do Intentions Predict Turnover Behavior? Human Relations, 1999.

WINTERTON, J. A conceptual model of labour turnover and retention. Human Resource Development International, v. 7, n. 3, p. 371-390, 2004.

WHIPPLE, J. M.; GRIFFIS, S. E.; DAUGHERTY, P. J. Conceptualizations of Trust: Can We Trust Them?. Journal of Business Logistics, v. 34, n. 2, p. 117130, 2013.

WORCHEL, P. Trust and distrust. In: AUSTIN, W. G; WORCHEL, S. (Eds). Social psychology of intergroup relations. Monterey: Brooks/Cole, p.174-187, 1979.

WRIGHT, P. M.; KEHOE, R. R. Organizational-Level Antecedents and Consequences of Commitment. In: BECKER, T. E.; KLEIN, H. J.; MEYER, J. P. (Org.), Commitment in Organizations. Accumulated Wisdom and New Directions. New York / London: Routledge - Taylor \& Francis Group, 2009.

YIN, R. K. Applications of case study research. Thousand Oaks, California: Sage Publications. 1993.

ZAHEER, A.; MCEVILY, B.; PERRONE, V. Does Trust Matter? Exploring the Effects of Interorganizational and Interpersonal Trust on Performance. Organization Science, v. 9, n. 2, p. 141-159, 1998.

ZANINI, M. T Confiança: o principal ativo intangível de uma empresa: pessoas, motivação e construção de valor. Rio de Janeiro, Elsevier, 2007.

LUSK, E.; WOLFF, B. Confiança dentro das Organizações da Nova Economia: uma Análise Empírica sobre as Conseqüências da Incerteza Institucional, n. 13, p. 72-91, 2009. 


\section{Anexo 1}

Ao responder este questionário é preciso que você pense na sua empresa como um todo e não apenas em sua área de atuação. A seguir são apresentadas frases ou perguntas que tratam de aspectos de sua organização. Para responder utilize o seguinte código:

$$
\begin{aligned}
& 1=\text { Discordo totalmente } \\
& 2=\text { Discordo } \\
& 3=\text { Nem concordo, nem discordo } \\
& 4=\text { Concordo } \\
& 5=\text { Concordo totalmente }
\end{aligned}
$$

Assinale suas respostas na última coluna, ao final de cada frase, com o número de 1 a 5 que melhor representa a sua opinião. Por favor, não deixe questões sem resposta. Lembre-se de que não há respostas certas ou erradas.

\begin{tabular}{|l|l|}
\hline \multicolumn{1}{|c|}{ ITEM: } & N \\
\hline $\begin{array}{l}\text { 1. Na sua organização, um colaborador pode ser demitido sem receber } \\
\text { explicações convincentes. }\end{array}$ & \\
\hline 2. A sua organização é ética. & \\
\hline 3. A sua organização considera apenas seus próprios interesses. & \\
\hline 4. Acredito na estabilidade financeira da sua organização. & \\
\hline $\begin{array}{l}\text { 5. O colaborador pode acreditar nas informações que a sua organização } \\
\text { divulga. }\end{array}$ & $\begin{array}{l}\text { 6. Para a sua organização, o cliente tem o direito de ser informado sobre os } \\
\text { assuntos que lhe dizem respeito. }\end{array}$ \\
\hline $\begin{array}{l}\text { 7. A sua organização oferece condições reais para que o colaborador se } \\
\text { desenvolva. }\end{array}$ & \\
\hline 8. A demissão de colaboradores segue um procedimento conhecido por todos. & \\
\hline
\end{tabular}




\begin{tabular}{|c|c|}
\hline $\begin{array}{l}\text { 9. O salário pago pela sua organização corresponde aos esforços do } \\
\text { colaborador. }\end{array}$ & \\
\hline 10. A sua organização segue normas para promover seus colaboradores. & \\
\hline $\begin{array}{l}\text { 11. Os dirigentes da sua organização demitem os colaboradores baseando-se } \\
\text { em julgamentos pessoais. }\end{array}$ & \\
\hline $\begin{array}{l}\text { 12. A sua organização oferece oportunidades de crescimento profissional ao } \\
\text { colaborador. }\end{array}$ & \\
\hline 13. A sua organização ocupa uma posição segura na sua área de atuação. & \\
\hline 14. As normas para demissão de colaboradores são claras. & \\
\hline 15. A sua organização está preparada para sobreviver às crises econômicas. & \\
\hline 16. Os contratos estabelecidos pela sua organização são vantajosos para todos. & \\
\hline $\begin{array}{l}\text { 17. A sua organização incentiva o crescimento profissional de seus } \\
\text { colaboradores. }\end{array}$ & \\
\hline 18. A solidez econômica da sua organização dá segurança aos colaboradores. & \\
\hline $\begin{array}{l}\text { 19. Os clientes da sua organização sabem que podem acreditar na solidez da } \\
\text { sua organização. }\end{array}$ & \\
\hline 20. A sua organização é conhecida por trabalhar de maneira responsável. & \\
\hline 21. A sua organização é conhecida pelo seu poder econômico. & \\
\hline 22. A sua organização valoriza o trabalho do colaborador financeiramente. & \\
\hline $\begin{array}{l}\text { 23. Aqui os colaboradores são demitidos a qualquer momento, independente } \\
\text { das normas da organização. }\end{array}$ & \\
\hline 24. Ser honesta com os clientes é princípio ético da sua organização. & \\
\hline 25. Aumentar salário é uma forma de reconhecimento da sua organização. & \\
\hline $\begin{array}{l}\text { 26. O plano de carreira da sua organização permite o crescimento profissional } \\
\text { do colaborador. }\end{array}$ & \\
\hline 27. O cliente é respeitado na sua organização. & \\
\hline $\begin{array}{l}\text { 28. O trabalho do colaborador é reconhecido na sua organização por meio do } \\
\text { salário. }\end{array}$ & \\
\hline
\end{tabular}

